\title{
Estimated Bycatch of Small Cetaceans in Northeast US Bottom Trawl Fishing Gear during 2000-2005
}

\author{
Marjorie C. Rossman \\ Northeast Fisheries Science Center, Protected Species Branch, 166 Water Street \\ Woods Hole, MA USA. Email: Marjorie.Rossman@noaa.gov
}

Rossman, M. C. 2010. Estimated bycatch of small cetaceans in northeast US bottom trawl fishing gear during 2000-2005. J. Northw. Atl. Fish. Sci., 42: 77-101. doi:10.2960/J.v42. m650

\begin{abstract}
The U.S. Marine Mammal Protection Act mandates monitoring of incidental marine mammal mortality and serious injury attributable to commercial fishing operations. Generalized linear models (GLM) applied to data collected on a sample of the fisheries were utilized to estimate incidental bycatch rates of pilot whales (Globicephela macrorhynchus and G. melas), white-sided dolphin (Lagenorhynchus acutus), and common dolphin (Delphinus delphis) in U.S. bottom trawl fisheries operating off the Northeast coast of the U.S. during 2000-2005. Spatial, habitat, environmental and fishing practice covariates were significant in the best fitting GLM models. Highest bycatch rates (observed bycatch per observed days fished) occurred in deeper waters with low sea surface temperature (whitesided dolphin), on vessels in the Mid-Atlantic region fishing in deeper waters (pilot whales), and in offshore waters (common dolphin). Estimated bycatch rates were expanded by total bottom trawl effort (days fished) to derive the mean annual bycatch mortality for each of the three species. The estimated mean annual bycatch during 2000-2005 for pilot whales, white-sided dolphin, and common dolphin in U.S. Atlantic bottom trawl fisheries is 72, 212 and 142 animals, respectively. These estimates are $29 \%, 42 \%$, and $14 \%$, respectively, of their current potential biological removal (PBR) levels for these three species. The importance of animal behavior in conjunction with vessel and gear characteristics associated with bycatch should be investigated further to learn more about potential mechanisms entrapping cetaceans in bottom trawl nets.
\end{abstract}

Keywords: AIC; bottom trawl; bycatch; common dolphin; dispersion; GLM; pilot whales; whitesided dolphin

\section{Introduction}

The Northeast U.S. continental shelf is a highly productive large marine ecosystem (LME) contributing to one of the nation's largest marine commercial fishing fleets (Fig. 1; NMFS, 1999; NMFS, 2004). This LME is also home to around 30 stocks of marine mammals (NMFS, 1999; Waring et al., 2007). The bottom trawl fleet accounts for the majority of fishing effort on the Northeast continental shelf (Stevenson et al., 2004). Fishing operations occur across the entire shelf and slope regions harvesting a variety of demersal and pelagic fish, and invertebrate species (Stevenson et al., 2004; NMFSNERO, 2008a). The co-existence of bottom trawl fishing and marine mammals contributes to accidental capture in the fishing gear, and subsequent death of non-targeted marine animals (Fertl and Leatherwood, 1997; Tregenza, 1998). This is commonly referred to as incidental bycatch or an incidental take (NMFS, 2004).
The U.S. Marine Mammal Protection Act of 1972, as amended in 2007, (MMPA) mandates monitoring marine mammal mortality and serious injury attributed to commercial fishing operations (http://www.nmfs.noaa. gov/pr/pdfs/laws/mmpa.pdf). This requires the regular assessment of marine mammal stock status so that they may rebuild to or maintain their optimal sustainable population levels, a primary goal of the MMPA. To determine marine mammal stock status, estimates of mortality attributable to commercial fishing operations are compared to the PBR value which is the product of minimum population size, one-half the maximum productivity rate, and a "recovery" factor (MMPA Sec. 3. 16 U.S.C. 1362; Wade and Angliss, 1997).

The National Marine Fisheries Service (NMFS) has divided the Northwest Atlantic Ocean (NWA) bottom trawl fishery into two regions, Northeast and Mid-Atlantic (Fig. 2; Federal Register, 2007). This paper focuses on 


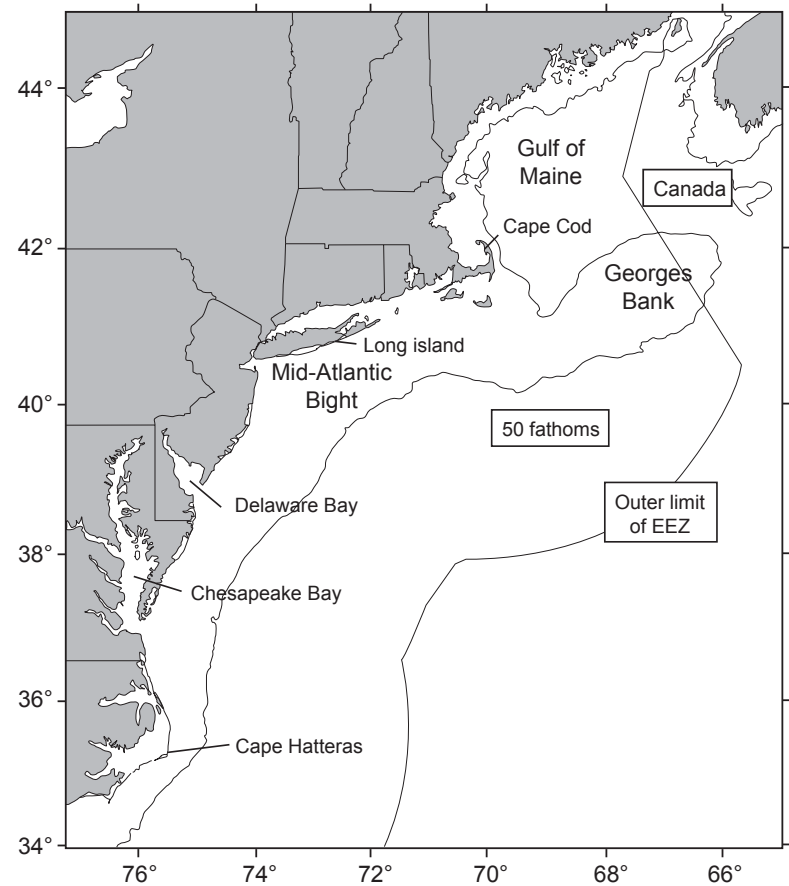

Fig. 1. Northeast US Shelf Ecosystem, showing the boundaries of the continental shelf (50-fathom line), the EEZ (200-mile limit), and the three principal ecosystems (Gulf of Maine, Georges Bank, and the Mid-Atlantic Bight). Source: Stevenson et al., 2004.

three cetacean species that have documented interactions in the NWA bottom trawl fishery: pilot whales (Globicephala spp.), white-sided dolphin (Lagenorhynchus acutus), and common dolphin (Delphinus delphis). There is insufficient data to accurately distinguish between bycatch of short-fin pilot whale (Globicephala macrorhynchus) and long-fin pilot whale (G. melas). As a result, all pilot whale take data were grouped and referred to as pilot whales (Globicephala spp.). All three species are regular inhabitants throughout the Northeastern U.S. LME. Although they have varying degrees of habitat preference, they are most commonly found along the continental shelf edge and western inshore Gulf of Maine (GOM) (Kenney and Winn, 1986; Payne and Heinemann, 1993; Palka et al., 1997; Waring et al., 2007). These are nutrient rich areas that support important prey items preferred by some toothed cetaceans. Pelagic schooling fishes, primarily Atlantic mackerel (Scomber scombrus), herring (Clupea harengus), and the squids Loligo (Loligo pealei) and Illex (Illex illecebrosus), are important prey items for pilot whales, white-sided dolphin and common dolphin. Demersal fish species may also be an important opportunistic component of their diet (Abend and Smith, MS 1999; Couperus, 1997; Waring, 1990).

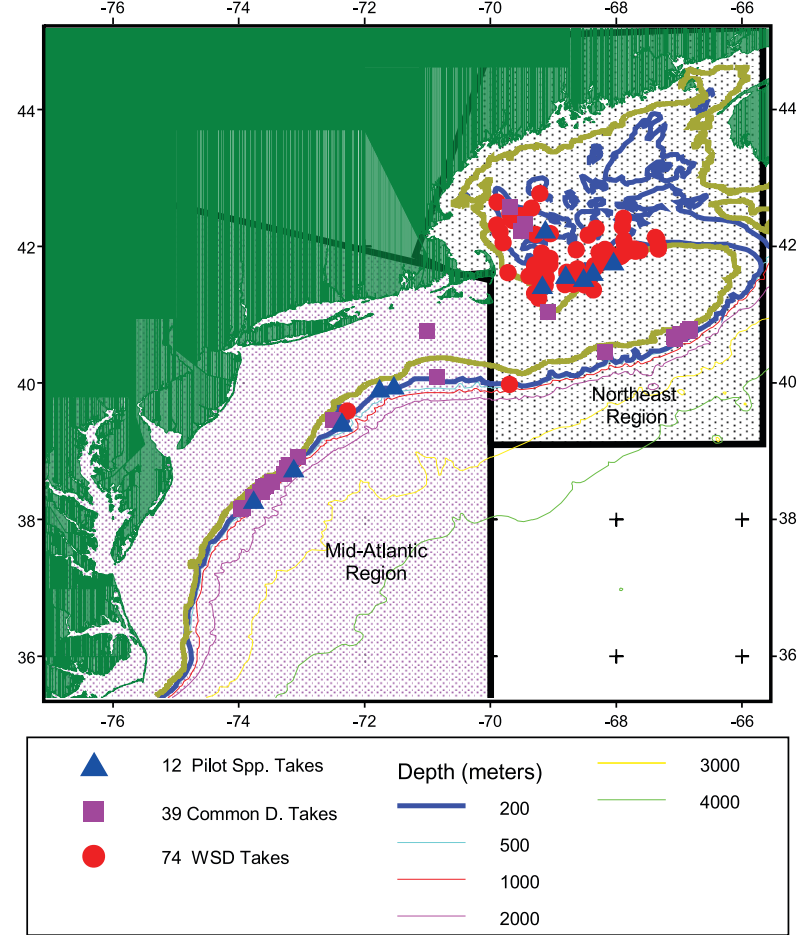

Fig. 2. Northeast and mid-Atlantic bottom trawl fishery regions are separated at $70^{\circ} \mathrm{W}$ longitude south of Cape Cod. The location and number of observed takes by species reported by the NEFOP from 2000-2005 are displayed along with bathymetry contours.

In this paper, fishery-dependent data collected from a sample of the NWA bottom trawl fishery are analyzed to estimate annual bycatch mortality from 2000-2005 for the three cetacean species. The primary objective was to build simple yet precise and accurate generalized linear models (GLMs) to predict the rate at which pilot whales, white-sided dolphin and common dolphin, are bycaught in bottom trawl gear per unit effort. Model predicted bycatch rates were then expanded to estimate total bycatch by applying the modeled bycatch rates to the total fishing effort of commercial fisheries. The total bycatch estimates for each species was then compared to the PBR value for each species.

Predictive models have become more common in recent years as a useful tool for not only predicting bycatch mortality but also to facilitate development of mitigation measures to reduce incidental bycatch of protected species (McCracken, MS 2004; Watson et al., 2005; Miller and Skalski, 2006; Garrison, 2007; Du Fresne et al., 2007; Murray, 2008). This paper presents the first estimates of small cetacean bycatch mortality attributed to bottom trawl gear in the NWA using a predictive model approach. Earlier estimates of small cetacean bycatch 
attributed to bottom trawl gear in NWA were generated using simple stratified ratio-estimators (Waring et al., 2007).

\section{Methods}

There are two primary sources of data necessary to estimate total incidental bycatch mortality. It is necessary to have both an estimate of total fishing effort for the bottom trawl fleet and a sample of the bottom trawl fleet where both effort and incidental bycatch are recorded. Bycatch rates (number of observed mortalities per observed fishing effort) are estimated from the sample which can then be expanded by total fishing effort of the fleet to estimate the total bycatch mortality.

Many gear and trip parameters were collected on the sampled bottom trawl trips. These parameters were used in a GLM framework to predict bycatch rates. Significant model parameters in essence stratify the data, thus resulting in improved precision of the estimated bycatch rates. The data sources and model development are discussed in further detail below.

To put the bycatch estimates in biological prospective, the bycatch estimate is compared to the PBR value for each species.

\section{Data sources}

Commercial fishing data. Commercial fisheries statistics for vessels fishing bottom trawl gear are collected under a mandatory reporting program (NMFS-NERO, 2008b). Data on individual fishing trips are recorded on paper forms known as vessel trip reports (VTR's), and includes data associated with temporal and spatial parameters of individual fishing trips (date, time, location, depth), operational parameters (tow duration, codend mesh size and foot rope length), and amount of fish (by species) landed for each trip. Environmental data (sea surface temperature and bottom slope) associated with each trip were obtained from other sources (see section on Environmental Data). VTR data are assumed to represent a census of Northeastern U.S. bottom trawl fishing effort (Maine to North Carolina) when used in fish stock assessments to manage these fisheries (Rago et al., 2005). Thus, the VTR effort data collected during 2000-2005 were assumed to represent the total bottom trawl fishery effort when estimating total annual bycatch of cetaceans in the bottom trawl fisheries.

Sampled commercial fishing data. The Northeast Fisheries Observer Program (NEFOP) collects data on vessel, trip, haul, and gear characteristics from a sample of commercial fishing vessels. Biological data are also obtained from target and non-target catch, and bycatch of protected species and sea birds (NMFS-NEFSC, 2008). The NEFOP database has over 100 gear and environmental variables, but only variables that were also available in the commercial fishery (VTR) data were considered for the bycatch rate model because the same data from the commercial fishery are required to estimate total bycatch (Table 1). All observed tows with a missing value for any of these variables were removed prior to modeling $(2.85 \%$ of the data records). Only bottom trawl trips targeting fish and pelagic invertebrates were analyzed; thus trips targeting sea scallops were not included.

Consistent collection of sea surface temperature while at sea (SST) on observed bottom trawl tows was not fully implemented until 2003. In addition, 40\% of observed tows did not have bottom depth information. Therefore, SST, bottom depth and bottom slope information for the beginning of each observed bottom trawl tow was derived from the same data sources used for the VTR data. (see section on Environmental Data).

The consistency of NEFOP sampling of the bottom trawl fleet across the region was analyzed by year and Statistical Area (Fig. 3; Appendix 1). Consistent annual sampling around GOM and Georges Bank (GB) in the northern regions of the Northeast continental shelf did not begin until 2000. Therefore, the time series selected for analysis is 1 January 2000 through 31 December 2005 (Appendix 1). A minimum of $2 \%$ mean annual sampling of commercial fishing trips was used as a benchmark for selecting Statistical Areas to include in the sampling dataset. A 2\% sampling is considered a sufficient level of coverage for developing pilot sampling programs for fisheries with unknown or limited data (NMFS, 2004). During 2000 to 2005, Statistical Areas inhabited by marine mammals with mean annual coverage near or at zero were excluded from the dataset. Statistical areas that had low coverage $(0.01-2 \%)$ were included with the caveat that the probability of observing bycatch in these areas was low during the time of sampling due to low coverage (Department of the Navy, 2005).

Bycatch is defined as any observed interaction where the animal's condition was recorded as either alive (with or without injuries) or fresh dead. Because trawl gear is actively towed for an average of 3.3 hours, it was assumed that the cause of death of animals with any stage of decomposition was not attributed to the gear and thus were excluded from the analysis. 
TABLE 1. List of variable descriptions collected by the NEFOP and used in building cetacean bycatch rate models. Data types for variables were either continuous (CO) or categorical (CA). Variables were abbreviated for analytical summaries.

\begin{tabular}{|c|c|c|}
\hline Variable $^{1}$ & Type & Description \\
\hline $\begin{array}{l}\text { Sea surface temperature } \\
\text { SST }\end{array}$ & $\mathrm{CO}$ & $\begin{array}{l}\text { Acquired from satellite data (see methods) obtained from date and position recorded } \\
\text { at the beginning of each observed tow. }\end{array}$ \\
\hline $\begin{array}{l}\text { Vessel length } \\
\text { Length }\end{array}$ & $\mathrm{CO}$ & The length of the vessel measured in feet. \\
\hline $\begin{array}{l}\text { Statistical area } \\
\text { Area }\end{array}$ & $\mathrm{CA}$ & $\begin{array}{l}\text { Statistical Area fished obtained from position data recorded from each observed tow } \\
\text { (Fig. 3); or grouped areas based on regression tree analyses (Table } 8 \text { ) }\end{array}$ \\
\hline Region & $\mathrm{CA}$ & $\begin{array}{l}\text { Represents the Northeast and Mid-Atlantic regions from grouping Statistical Areas } \\
\text { east and west of } 70^{\circ} \mathrm{W} \text {-longitude, respectively (Fig. 3). }\end{array}$ \\
\hline $\begin{array}{l}\text { Bottom slope } \\
\text { Slope }\end{array}$ & $\mathrm{CO}$ & $\begin{array}{l}\text { Acquired from bathymetry data (see methods) obtained from position recorded at the } \\
\text { beginning of each observed tow. }\end{array}$ \\
\hline $\begin{array}{l}\text { Bottom depth } \\
\text { Depth }\end{array}$ & $\mathrm{CO}$ & $\begin{array}{l}\text { Water depth recorded at the beginning of each observed tow (original unit in fathoms } \\
\text { was converted to meters). }\end{array}$ \\
\hline $\begin{array}{l}\text { Gross tons } \\
\text { Gtons }\end{array}$ & $\mathrm{CO}$ & The vessels gross registered tonnage. \\
\hline $\begin{array}{l}\text { Vessel horse power } \\
V H P\end{array}$ & $\mathrm{CO}$ & The vessels engine power. \\
\hline $\begin{array}{l}\text { Latitude } \\
\text { Lat }\end{array}$ & $\mathrm{CO}$ & The latitude location where the observed tow began. \\
\hline $\begin{array}{l}\text { Longitude } \\
\text { Lon }\end{array}$ & $\mathrm{CO}$ & The longitude location where the observed tow began. \\
\hline Year & $\mathrm{CO}$ & The year that the vessel first arrives in port where the kept catch is sold. \\
\hline Month & $\mathrm{CO}$ & The month that the vessel first arrives in port where the kept catch is sold. \\
\hline State & $\mathrm{CA}$ & $\begin{array}{l}\text { The state where the vessel landed its kept catch; or grouped states based on regres- } \\
\text { sion tree analyses (Table } 8 \text { ). }\end{array}$ \\
\hline $\begin{array}{l}\text { Haul duration } \\
\text { Hauldur }\end{array}$ & $\mathrm{CO}$ & $\begin{array}{l}\text { A calculated variable recorded as the difference between the time when gear is set in } \\
\text { to the water and when the hauling gear is engaged for net retrieval. }\end{array}$ \\
\hline $\begin{array}{l}\text { Fish kept } \\
\text { Fshkpt }\end{array}$ & $\mathrm{CO}$ & The total tow weight (metric tons) of fish kept. \\
\hline $\begin{array}{l}\text { Fish group } \\
\text { Fshgrp }\end{array}$ & $\mathrm{CA}$ & $\begin{array}{l}\text { A calculated variable where individual kept species were grouped into categories } \\
\text { based on regression tree analyses (Table } 8 \text { ) }\end{array}$ \\
\hline $\begin{array}{l}\text { Fish species } \\
\text { Species }\end{array}$ & CA & The common name of the primary fish species sought for each observed tow. \\
\hline $\begin{array}{l}\text { Foot rope length } \\
\text { Ftroplen }\end{array}$ & $\mathrm{CO}$ & The length (feet) of the rope along the bottom of the trawl net. \\
\hline $\begin{array}{l}\text { Days fished } \\
\text { Dysfish }\end{array}$ & $\mathrm{CO}$ & A calculated variable recorded as the haul duration divided by 24 hours. \\
\hline $\begin{array}{l}\text { Bottom type } \\
\text { Sediment }\end{array}$ & CA & $\begin{array}{l}\text { Acquired from USGS sediment data (see methods) obtained from the position re- } \\
\text { corded at the beginning of each observed tow. }\end{array}$ \\
\hline $\begin{array}{l}\text { Time of day } \\
\text { TOD }\end{array}$ & $\mathrm{CA}$ & $\begin{array}{l}\text { A calculated variable based on timing of the sunrise and sunset relative on the day of } \\
\text { the haul back. Categories were daytime, nighttime, dawn and dusk; ( }+/-1 \text { hour). }\end{array}$ \\
\hline
\end{tabular}

1 Codend mesh size was excluded from the final set of variables used for model building due to the relatively large amount of missing values in the NEFOP data set. 


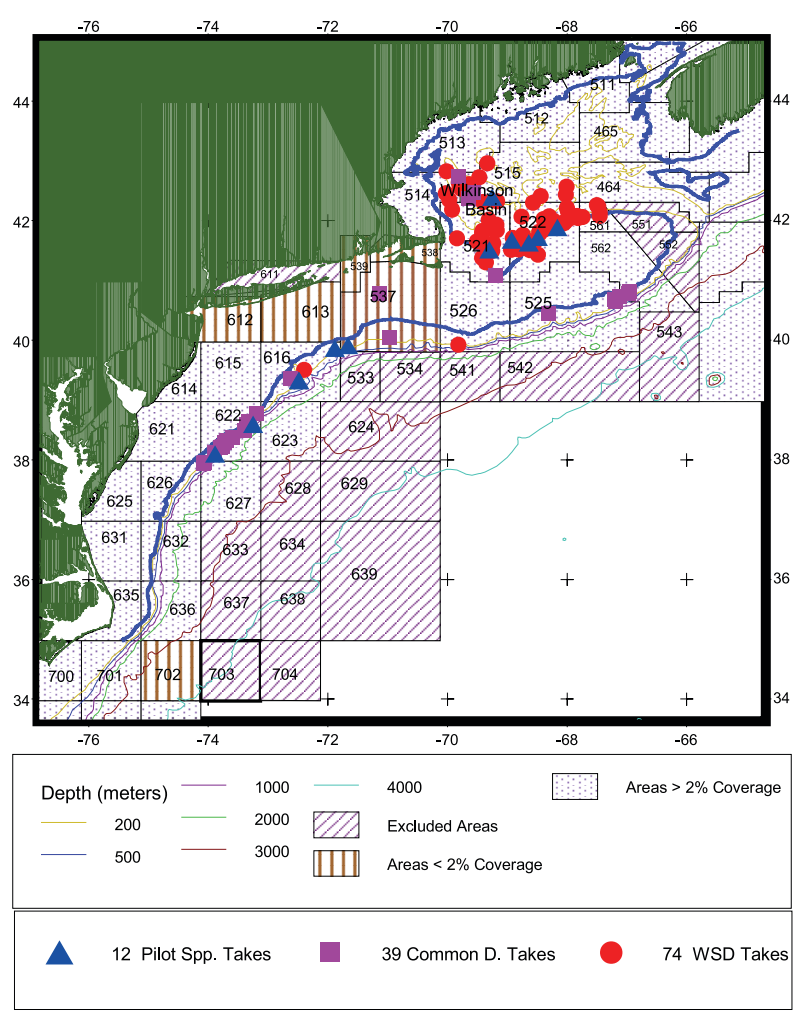

Fig. 3. Chart of Statistical Areas and takes observed from 2000-2005 by the NEFOP in the bottom trawl fishery on the Northeast U.S continental shelf. Areas with no coverage or coverage near zero were excluded. Areas that are inhabited year round by marine mammals but had low mean annual levels of coverage $(<2 \%)$ were included with the caveat that the probability of observing takes in these areas was low during the time of sampling due to low coverage.

Environmental data. Using ArcGIS 9.1 software, and data on the position (latitude and longitude) and date (day and year) from both tows observed by the NEFOP and trips reported on VTRs were used to extract satellite derived data for SST and bathymetry data (bottom depth and bottom slope) using the methods described in Warden and Orphanides (2008). Sediment data that describes bottom type was acquired from the Unites States Geological Survey (USGS) east coast sediment data base. Additional information on the USGS east coast sediment analysis can be found at: http://pubs.usgs.gov/of/2000/ of00-358/ .

\section{Analytic approach}

Model building to estimate bycatch rates. The number of bycaught animals per tow varied from zero to seven animals per tow (Table 2). Thus, the species bycatch rates were modeled in a generalized linear model
TABLE 2. Descriptive statistics for bycatch of cetaceans in bottom trawl tows observed during 2000 to 2005 . Frequency $(f)$ of tows with the number of bycaught animals (count) per tow, mean take rate per tow (total number of takes divided by total number of tows), variance, and coefficient of dispersion ( $C D$; variance divided by the mean) are reported by species.

\begin{tabular}{lrrr}
\hline \hline Takes & Pilot whale \\
(count) & $\begin{array}{c}\text { White-sided } \\
\text { dolphin } \\
\text { (tows) }\end{array}$ & $\begin{array}{c}\text { Common } \\
\text { (tows) }\end{array}$ & \begin{tabular}{c}
$f$ (tows) \\
\hline 0
\end{tabular} \\
51663 & 51610 & 51650 \\
1 & 12 & 61 & 18 \\
2 & 0 & 3 & 4 \\
3 & 0 & 0 & 2 \\
7 & 0 & 1 & 1 \\
Total \# takes & 12 & 74 & 39 \\
Total \# tows & 51675 & 51675 & 51675 \\
Mean take per & & & \\
tow & 0.000232 & 0.001432 & 0.000755 \\
Variance & 0.000232 & 0.002359 & 0.001954 \\
$C D$ & 1.00 & 1.65 & 2.59 \\
\hline
\end{tabular}

(GLM) framework assuming a quasi-Poisson distribution. The dispersion assumption of the Poisson distribution was investigated. Data that are truly over (or under) dispersed can not be remedied by transformations or regression on associated covariates (Cameron and Trivedi, 1998) and can only be addressed by models that explicitly account for truncated or inflated zeros in the data (e.g. hurdle, negative-binomial or zero-inflated models). Thus, the zero-inflated model framework (ZIP) was also investigated.

The following steps were followed to build a predictive model for each cetacean species. First, each dependent variable was modeled separately against each cetacean response variable with an offset variable (null model) to predict the rate at which cetacean species were bycaught per unit effort (days fished) in the bottom trawl fishery (Table 1). Second, the goodness of fit (GOF) of each uni-variate model was assessed using the analysis of variance (ANOVA) and Akaike information criteria (AIC; Burnham and Anderson, 2002), respectively. Third, continuous covariates were log transformed to improve fit. Fourth, transformed continuous covariates that were significant and had lower AIC scores relative to the other variables were then categorized to assess further improvements in AIC scores. Regression trees were used to categorize significant continuous covariates and 
reduce the number of levels for categorical variables that initially showed significant association with response variables. Several different group categories were explored and final categories were selected based on the lowest AIC score. Fifth, all the models were sorted by their AIC score from lowest to highest AIC. Covariates with coefficient of dispersion (CD) near one were preferred over covariates that had the same AIC score, where the $\mathrm{CD}$ is defined as the variance divided by the mean.

The regression trees were used to create meaningful break points for continuous variables so that the categorized predictors had lower AIC scores than their continuous counterpart. Original categorical variables that were significant but had high AIC scores because of too many levels had levels pooled so that AIC scores decreased when grouped to fewer levels. Therefore, all the final models developed to predict cetacean bycatch rates were built from the best fitting univariate models using categorized covariates with the lowest AIC scores (Tables 3-5).

Final model selection was based on several factors: (1) the overall fit of the model based on the AIC; (2) the GOF of the predicted bycatch compared to observed

TABLE 3. Pilot whale species: summary of results from the univariate GLM analysis. The table lists the predictors tested, data type - continuous (CO) or categorical (CA), residual degrees of freedom (d.f.), residual unexplained deviance (Res. Dev.), the Akaike Information Criteria statistic (AIC), coefficient of dispersion $(C D)$ and statistical significance ( $P$-value) from ANOVA $F$-test. Continuous variables were logtransformed. Univariate models with lowest AIC's are bold.

\begin{tabular}{|c|c|c|c|c|c|c|}
\hline \multirow[b]{2}{*}{ Predictors } & \multirow[b]{2}{*}{ Type } & \multirow{2}{*}{$\begin{array}{c}\text { Residual } \\
\text { d.f. }\end{array}$} & \multicolumn{4}{|c|}{ Pilot whale species } \\
\hline & & & $C D$ & Res. Dev. & AIC & $P$-value \\
\hline $\begin{array}{l}\text { Null model } \\
\text { w/offset }\end{array}$ & & 51674 & 0.91 & 197 & 199 & \\
\hline SST & $\mathrm{CO}$ & 51673 & 0.92 & 197 & 201 & 0.067 \\
\hline Depth & CA & 51672 & 0.79 & 175 & 181 & $<0.001$ \\
\hline Depth & $\mathrm{CO}$ & 51673 & 0.76 & 191 & 195 & 0.005 \\
\hline Bottom slope & $\mathbf{C A}$ & 51673 & 0.92 & 187 & 191 & 0.001 \\
\hline Bottom slope & $\mathrm{CO}$ & 51673 & 0.73 & 183 & 187 & $<0.001$ \\
\hline Lat & $\mathrm{CO}$ & 51673 & 0.73 & 191 & 195 & 0.004 \\
\hline Lon & $\mathrm{CO}$ & 51673 & 0.73 & 190 & 194 & 0.001 \\
\hline State & $\mathrm{CA}$ & 51665 & 0.65 & 176 & 196 & $<0.001$ \\
\hline Area & $\mathrm{CA}$ & 51643 & 0.38 & 169 & 233 & 2.318 \\
\hline Region & CA & 51673 & 0.73 & 186 & 190 & $<0.001$ \\
\hline Gtons & $\mathrm{CO}$ & 51673 & 0.83 & 194 & 198 & 0.076 \\
\hline Length & $\mathrm{CO}$ & 51673 & 0.83 & 194 & 198 & 0.073 \\
\hline VHP & CA & 51673 & 0.93 & 189 & 193 & 0.003 \\
\hline VHP & $\mathrm{CO}$ & 51673 & 0.81 & 191 & 195 & 0.005 \\
\hline Fshkpt & $\mathrm{CO}$ & 51673 & 0.91 & 197 & 201 & 0.978 \\
\hline Ftroplen & $\mathrm{CO}$ & 51673 & 0.86 & 192 & 196 & 0.015 \\
\hline Hauldur & $\mathrm{CO}$ & 51673 & 0.94 & 197 & 201 & 0.051 \\
\hline Dysfish & $\mathrm{CO}$ & 51673 & 0.95 & 198 & 202 & 0.082 \\
\hline Species & CA & 51674 & 0.40 & 168 & 224 & $<0.001$ \\
\hline Fishgrp & $\mathbf{C A}$ & 51673 & 0.70 & 178 & 182 & $<0.001$ \\
\hline Sediment & $\mathrm{CA}$ & 51664 & 0.60 & 183 & 205 & 0.010 \\
\hline Year & $\mathrm{CO}$ & 51673 & 0.90 & 197 & 201 & 0.740 \\
\hline Month & $\mathrm{CO}$ & 51673 & 0.97 & 196 & 200 & 0.262 \\
\hline TOD & $\mathrm{CA}$ & 51671 & 0.89 & 195 & 203 & 0.440 \\
\hline
\end{tabular}


TABLE 4. White-sided dolphins: summary of results from the univariate GLM analysis. The table lists the predictors tested, data type - continuous (CO) or categorical (CA), residual degrees of freedom (d.f.), residual unexplained deviance (Res. Dev.), the Akaike Information Criteria statistic (AIC), coefficient of dispersion $(C D)$ and statistical significance $(P$-value) from ANOVA $F$-test. Continuous variables were log-transformed. Univariate models with lowest AIC's are bold.

\begin{tabular}{lcccccc}
\hline \hline & & Residual & \multicolumn{5}{c}{ White-sided dolphin } \\
\cline { 6 - 8 } Predictors & Type & d.f. & CD & Res. Dev. & AIC & $P$-value \\
\hline Null model & & & & & & \\
w/offset & & 51674 & 1.28 & 973 & 975 & \\
SST & CA & $\mathbf{5 1 6 7 2}$ & $\mathbf{1 . 1 1}$ & $\mathbf{8 7 8}$ & $\mathbf{8 8 4}$ & $\mathbf{0 . 0 0 1}$ \\
SST & CO & 51673 & 1.58 & 888 & 892 & $<0.001$ \\
Depth & CA & $\mathbf{5 1 6 7 3}$ & $\mathbf{1 . 4 3}$ & $\mathbf{9 0 0}$ & $\mathbf{9 0 4}$ & $<\mathbf{0 . 0 0 1}$ \\
Depth & CO & 51673 & 0.99 & 902 & 906 & 0.001 \\
Slope & CO & 51673 & 1.27 & 971 & 975 & 0.270 \\
Lat & CO & 51673 & 1.19 & 959 & 963 & $<0.001$ \\
Lon & CO & 51673 & 1.20 & 968 & 972 & 0.052 \\
State & CA & 51665 & 1.23 & 950 & 970 & 0.027 \\
Area & CA & $\mathbf{5 1 6 7 2}$ & $\mathbf{1 . 1 5}$ & $\mathbf{9 0 2}$ & $\mathbf{9 0 8}$ & $<\mathbf{0 . 0 0 1}$ \\
Region & CA & 51673 & 1.25 & 951 & 955 & 0.002 \\
Gtons & CO & 51673 & 1.28 & 968 & 972 & 0.049 \\
Length & CO & 51673 & 1.22 & 965 & 969 & 0.010 \\
VHP & CO & 51673 & 1.33 & 972 & 976 & 0.329 \\
Fshkpt & CO & 51673 & 1.67 & 1004 & 977 & 0.648 \\
Ftroplen & CO & 51673 & 1.41 & 964 & 968 & $<0.001$ \\
Hauldur & CO & 51673 & 1.38 & 951 & 955 & $<0.001$ \\
Dysfish & CO & 51673 & 1.31 & 955 & 959 & $<0.001$ \\
Species & CA & 51647 & 0.86 & 910 & 966 & $<0.001$ \\
Fshgrp & CA & $\mathbf{5 1 6 7 3}$ & $\mathbf{1 . 0 0}$ & $\mathbf{9 1 8}$ & $\mathbf{9 2 2}$ & $<\mathbf{0 . 0 0 1}$ \\
Sediment & CA & 51664 & 1.15 & 943 & 965 & 0.077 \\
Year & CO & 51673 & 1.12 & 947 & 951 & $<0.001$ \\
Month & CO & 51673 & 1.04 & 923 & 927 & $<0.001$ \\
Month & CA & $\mathbf{5 1 6 7 3}$ & $\mathbf{1 . 0 7}$ & $\mathbf{8 8 5}$ & $\mathbf{8 8 9}$ & $\mathbf{0 . 0 0 1}$ \\
\hline & & 51671 & 1.27 & 961 & 969 & 0.833 \\
\hline
\end{tabular}

bycatch stratified by the model parameters; (3) models with a coefficient of dispersion near one were preferred; and (4) models that have a minimum of 5-10 positive observations (takes) per parameter to reduce risk of over-fitting and increase parsimony (Harrell et al., 1984; Stokes et al., 1995). Factor 4 (models with higher parsimony relative to simpler models) was given priority over the other factors for final model selection. A preliminary set of binomial and zero inflated Poisson (ZIP) models were also evaluated in the search for the best model to predict cetacean bycatch rates. However, the apparent varying degrees of over or (under) dispersion was remedied by different significant regressors during model building. As a result, the ZIP models were not pursued any further.

Bycatch estimates. Bycatch $(T)$ estimates for each cetacean species $(i)$ were calculated as the product of the model estimated bycatch rates $(R)$ multiplied by total days fished $(E)$ from each strata $(j)$ as defined by the 
TABLE 5. Common dolphins: summary of results from the univariate GLM analysis. The table lists the predictors tested, data type - continuous (CO) or categorical (CA), residual degrees of freedom (d.f.), residual unexplained deviance (Res. Dev.), the Akaike Information Criteria statistic (AIC), coefficient of dispersion $(C D)$ and statistical significance ( $P$-value) from ANOVA $F$-test. Continuous variables were log-transformed. Univariate models with lowest AIC's are bold.

\begin{tabular}{|c|c|c|c|c|c|c|}
\hline \multirow[b]{2}{*}{ Predictors } & \multirow[b]{2}{*}{ Type } & \multirow{2}{*}{$\begin{array}{c}\text { Residual } \\
\text { d.f. }\end{array}$} & \multicolumn{4}{|c|}{ Common dolphin } \\
\hline & & & $C D$ & Res. Dev. & AIC & $P$-value \\
\hline $\begin{array}{l}\text { Null model } \\
\text { w/offset }\end{array}$ & & 51674 & 2.27 & 599 & 601 & \\
\hline SST & $\mathrm{CO}$ & 51673 & 2.05 & 590 & 594 & 0.030 \\
\hline Depth & $\mathrm{CO}$ & 51673 & 2.35 & 578 & 582 & 0.002 \\
\hline Slope & $\mathbf{C A}$ & 51673 & 1.44 & 514 & 518 & $<0.001$ \\
\hline Slope & $\mathrm{CO}$ & 51673 & 1.62 & 543 & 547 & $<0.001$ \\
\hline Lat & $\mathbf{C A}$ & 51672 & 1.20 & 513 & 519 & $<0.001$ \\
\hline Lat & $\mathrm{CO}$ & 51673 & 0.95 & 528 & 532 & 0.001 \\
\hline Lon & $\mathrm{CO}$ & 51673 & 1.36 & 534 & 538 & $<0.001$ \\
\hline State & CA & 51673 & 0.89 & 483 & 487 & 0.001 \\
\hline Area & $\mathbf{C A}$ & 51671 & 0.87 & 447 & 455 & 0.001 \\
\hline Region & $\mathrm{CA}$ & 51673 & 1.12 & 515 & 519 & 0.001 \\
\hline Gtons & $\mathrm{CO}$ & 51673 & 1.92 & 587 & 591 & 0.010 \\
\hline Length & $\mathrm{CO}$ & 51673 & 2.08 & 591 & 595 & 0.048 \\
\hline VHP & $\mathrm{CO}$ & 51673 & 1.54 & 569 & 573 & $<0.001$ \\
\hline Fshkpt & $\mathrm{CO}$ & 51673 & 1.97 & 569 & 573 & $<0.001$ \\
\hline Ftroplen & $\mathrm{CO}$ & 51673 & 2.03 & 590 & 594 & 0.032 \\
\hline Hauldur & $\mathrm{CO}$ & 51673 & 2.32 & 597 & 603 & 0.609 \\
\hline Dysfish & $\mathrm{CO}$ & 51673 & 2.31 & 599 & 603 & 0.741 \\
\hline Species & $\mathrm{CA}$ & 51647 & 0.45 & 438 & 494 & 0.001 \\
\hline Fshgrp & $\mathrm{CA}$ & 51672 & 1.10 & 459 & 465 & 0.001 \\
\hline Sediment & $\mathrm{CA}$ & 51664 & 2.21 & 575 & 597 & 0.373 \\
\hline Year & $\mathrm{CO}$ & 51673 & 2.26 & 599 & 603 & 0.940 \\
\hline Month & $\mathrm{CO}$ & 51673 & 1.66 & 581 & 585 & 0.001 \\
\hline TOD & CA & 51671 & 2.05 & 594 & 602 & 0.491 \\
\hline
\end{tabular}

model covariates, region ( $k$-Northeast $v s$. Mid-Atlantic), and year $(l)$ :

$$
T_{i}=R_{i j} E_{j k l}
$$

Bycatch estimates by cetacean species were summed over all strata within region and year to estimate total bycatch and then averaged for 2000-2005 to estimate the annual mean bycatch.
Observed trips were re-sampled 1000 times within strata using standard bootstrapping techniques to generate standard error (SE) statistics for the bycatch rate models (Efron and Tibshirani, 1993). Coefficient of variation (CV) statistics (SE/bycatch rate) were then calculated for the annual and mean takes estimates. It was assumed that the VTR effort statistics (days fished) represented a census of the bottom trawl fleet (Rago et al., 2005). As 
a result there are no variance estimates associated with the VTR effort.

\section{Results}

\section{Observed bycatch}

Between the years 2000 and 2005 there were 51675 bottom trawl tows observed. During this time period there were 12 pilot whales, 74 white-sided dolphin and 39 common dolphin observed taken in the gear (Table 2).

Six pilot whales were observed in the Northeast region during April and June in the multi-species groundfish fishery and six were also observed in the Mid-Atlantic region between August and December in the Illex and Loligo squid fisheries (Fig. 3).

With the exception of one animal, all 74 white-sided dolphin were observed in the Northeast region around Wilkinsons Basin and north-western GB, where the one exception was taken on south-western GB (Fig. 3). The majority $(66 \%)$ of white-sided dolphin were observed during the months of March and April in the multi-species groundfish fishery.

Ten common dolphin were observed in the Northeast region in Wilkinson Basin and GB, while 29 (74\%) animals were observed in the Mid-Atlantic region concentrated in offshore Statistical Area 622 (Fig. 3). Common dolphin takes were observed in the Northeast region during July through February in the mixed groundfish and Loligo squid fisheries, in contrast to the takes in the Mid-Atlantic region where 59\% (17/29) of the observed takes were taken in December and March in the offshore Loligo squid fishery (Fig. 3).

\section{Bycatch rates and total bycatch estimates}

Pilot whales. Total mean annual bycatch estimates of pilot whales from 2000-2005, over both regions and all strata was $72(\mathrm{CV}=0.13)$ animals (Table 6). On average, $24 \%$ and $76 \%$ of the bycatch came from the Northeast and Mid-Atlantic regions, respectively. Over both regions, $70 \%$ of the mean annual bycatch came from vessels fishing in mid-depth waters, 19\% came from deep waters, and less than $11 \%$ of the mean annual bycatch came from shallow waters (Table 6).

Relative to the null model AIC (199), the best univariate predictors of pilot whale bycatch were the following categorical variables: depth $(\mathrm{AIC}=181)$, fshgrp
$(\mathrm{AIC}=182)$, region $(\mathrm{AIC}=190)$, slope $(\mathrm{AIC}=191)$ and VHP (AIC = 193; Table 3). The best fitting model chosen included depth and region $(\mathrm{AIC}=168$; Table 7 ). The addition of slope and VHP did describe some of the additional variance in the data as shown by a decreasing dispersion statistic however they did not change the AIC (Table 7). Several of the models are reasonable (AIC values within 4-8 of the lowest AIC according to Burnham and Anderson, 2002). However, an additional criterion for selecting a final model includes parsimony. Therefore, the final GLM log-linear predictor for predicting pilot whale bycatch rates is defined as:

$$
\begin{gathered}
\text { PilotWhaleTakes/DaysFished }=\exp (-5.897+ \\
0.856 \text { MidDepth }-1.081 \text { ShallowDepth }+ \\
\text { 1.223 Mid-AtlanticRegion) }
\end{gathered}
$$

where depth is defined by three categories (ShallowDepth is $<144.07 \mathrm{~m}$; MidDepth is $144.07-162.58 \mathrm{~m}$; and deep is $>162.58 \mathrm{~m}$ ) and region is defined by two categories (Northeast and Mid-Atlantic; Fig. 2; Table 8). The partial residual plots show that the bycatch rate of pilot whales is much higher in the Mid-Atlantic region than in the Northeast region (Fig. 4). The larger residuals for observations from the deep and mid depth categories are probably due to smaller amounts of fishery effort and low observer coverage in the deep and mid depths relative to shallow depth effort (Table 9). The predicted number of bycaught pilot whales compared to the observed bycatch indicates the final model fits well (Fig. 5).

The estimated bycatch rates ranged from a low of $0.00009(\mathrm{CV}=1.11)$ animals per day fished in shallow depth waters in the Northeast region to a high of 0.06477 $(\mathrm{CV}=0.48)$ animals per day fished in mid-depth waters in the Mid-Atlantic region (Table 6). The bycatch rates in the Mid-Atlantic region are generally larger than the bycatch rates in the Northeast region. The VTR data from 2000 to 2005 indicate that on average, over both regions, $65 \%$ of the fishing effort came from vessels fishing in shallow waters, $11 \%$ from the mid-depths and $24 \%$ from deep waters. Because pilot whales are most commonly found in deeper water associated with steep sloped habitat, the probability of interaction is higher for vessels fishing in deep waters, however, the majority of fishing effort takes place in shallow waters.

White-sided dolphin. Total mean annual bycatch estimates of white-sided dolphin from 2000-2005, over all strata from both regions was $212(\mathrm{CV}=0.11)$ animals. On average, the majority $(82 \%)$ of the bycatch came from vessels fishing in deep waters where $26 \%, 37 \%$ and $19 \%$ came from waters with low, mid and high SST, respectively (Table 10). 


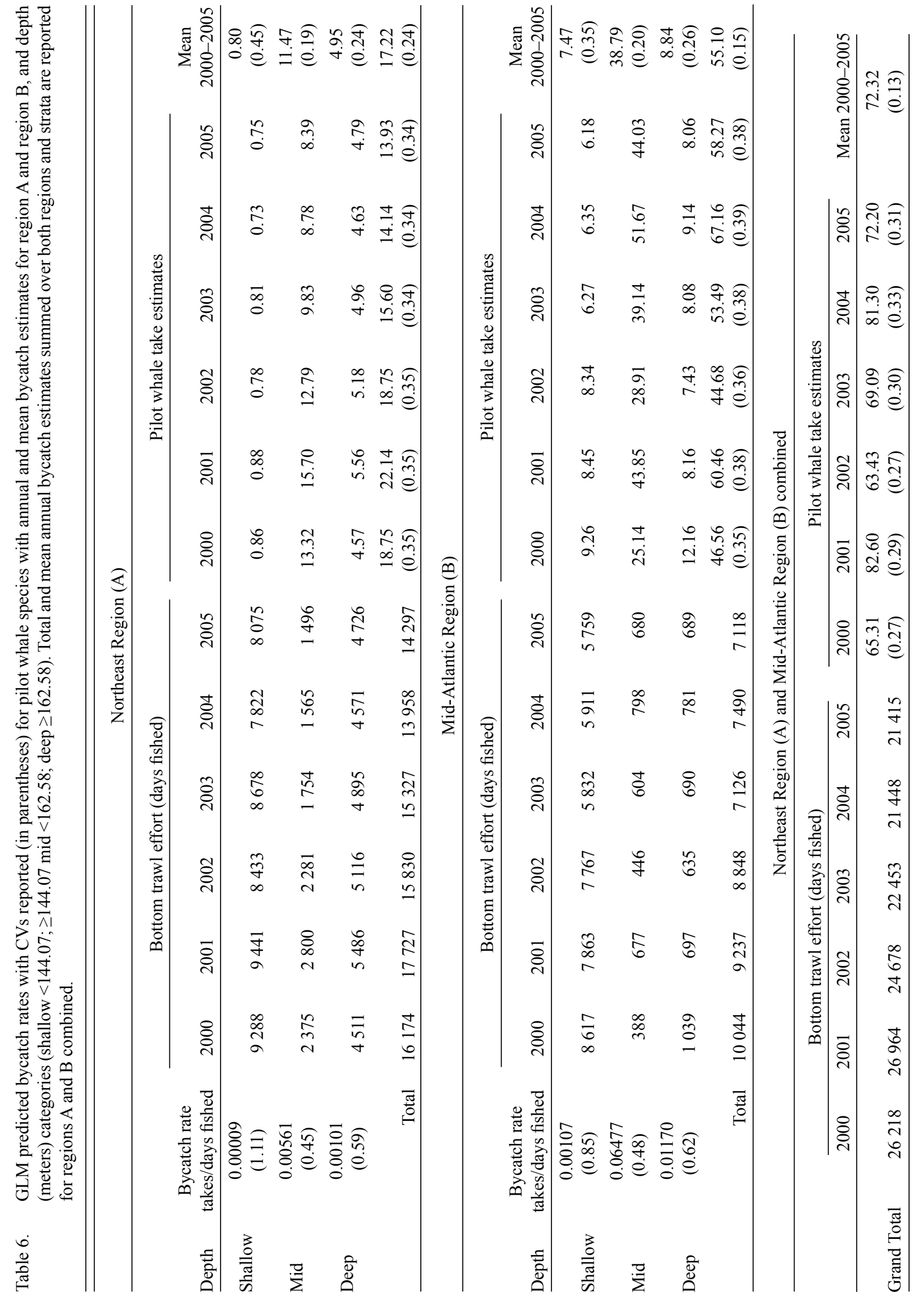


TABLE 7. Final model (shown in bold) selection for predicting the bycatch rate of pilot whales, white-sided dolphins, and common dolphins. Analysis of residual degrees of freedom $(d f)$ and deviance $(D)$, AIC score, coefficient of dispersion $(C D)$, and parameter ratio (\# of positive observations / \# parameters) are shown. Final models selection was based on the fit of the model (AIC), degree of dispersion, parameter ratio and GOF (Fig. 5).

\begin{tabular}{|c|c|c|c|c|c|c|}
\hline Model & Linear predictor & Residual $d f$ & Residual $D$ & AIC & $C D$ & $\begin{array}{c}\text { Parameter } \\
\text { ratio }\end{array}$ \\
\hline \multicolumn{7}{|c|}{ Pilot whales } \\
\hline \multirow[t]{13}{*}{ Null } & Pilot $\sim$ offset & 51674 & 197 & 199 & 0.91 & \\
\hline & Pilot $\sim$ VHP & 51673 & 189 & 193 & 0.93 & 12.0 \\
\hline & Pilot $\sim$ Slope & 51673 & 187 & 191 & 0.92 & 12.0 \\
\hline & Pilot $\sim$ Region & 51673 & 186 & 190 & 0.73 & 12.0 \\
\hline & Pilot $\sim$ Fshgrp & 51673 & 178 & 182 & 0.70 & 12.0 \\
\hline & Pilot $\sim$ Depth & 51672 & 175 & 181 & 0.79 & 6.0 \\
\hline & Pilot $\sim$ Depth + Region + Slope + VHP & 51669 & 156 & 168 & 1.08 & 2.4 \\
\hline & Pilot $\sim$ Depth + Region + Slope & 51670 & 158 & 168 & 1.17 & 3.0 \\
\hline & Pilot $\sim$ Depth + Region + VHP & 51670 & 157 & 167 & 1.18 & 3.0 \\
\hline & Pilot $\sim$ Depth + Region & 51671 & 160 & 168 & 1.31 & 4.0 \\
\hline & Pilot $\sim$ Depth + Fshgrp + Slope & 51670 & 158 & 168 & 0.87 & 3.0 \\
\hline & Pilot $\sim$ Depth + Fshgrp + VHP & 51670 & 157 & 167 & 0.84 & 3.0 \\
\hline & Pilot $\sim$ Depth + Fshgrp & 51671 & 160 & 168 & 0.90 & 4.0 \\
\hline \multicolumn{7}{|c|}{ White-sided dolphins } \\
\hline \multirow[t]{10}{*}{ Null } & White $\sim$ offset & 51674 & 973 & 975 & 1.28 & \\
\hline & White $\sim$ Depth & 51673 & 900 & 904 & 1.43 & 74.0 \\
\hline & White $\sim$ Area & 51672 & 902 & 908 & 1.15 & 37.0 \\
\hline & White $\sim$ Fshgrp & 51673 & 918 & 922 & 1.00 & 74.0 \\
\hline & White $\sim$ SST & 51672 & 878 & 884 & 1.11 & 37.0 \\
\hline & White $\sim$ SST + Depth + Area + Fshgrp & 51668 & 810 & 824 & 1.09 & 12.3 \\
\hline & White $\sim$ SST + Depth + Area & 51669 & 821 & 833 & 1.14 & 14.8 \\
\hline & White $\sim$ SST + Depth + Fshgrp & 51670 & 828 & 838 & 1.08 & 18.5 \\
\hline & White $\sim$ SST + Depth & 51671 & 842 & 850 & 1.75 & 24.7 \\
\hline & \multicolumn{6}{|c|}{ Common dolphins } \\
\hline Null & Common $\sim$ offset & 51674 & 599 & 601 & 2.27 & \\
\hline & Common $\sim$ Lat & 51672 & 513 & 519 & 1.20 & 19.5 \\
\hline & Common $\sim$ Slope & 51673 & 514 & 518 & 1.44 & 39.0 \\
\hline & Common $\sim$ State & 51673 & 483 & 487 & 0.89 & 39.0 \\
\hline & Common $\sim$ Fshgrp & 51672 & 459 & 465 & 1.10 & 19.5 \\
\hline & Common $\sim$ Area & 51671 & 447 & 455 & 0.87 & 13.0 \\
\hline & Common $\sim$ Area + Fshgrp + Sate + Slope & 51667 & 408 & 424 & 0.78 & 5.6 \\
\hline & Common $\sim$ Area + Fshgrp + State & 51668 & 408 & 422 & 0.78 & 6.5 \\
\hline & Common $\sim$ Area + Fshgrp & 51669 & 414 & 426 & 0.88 & 7.8 \\
\hline & Common $\sim$ State + Fshgrp & 51671 & 444 & 452 & 0.64 & 13.0 \\
\hline & Common $\sim$ Slope + Fshgrp & 51671 & 456 & 464 & 0.93 & 13.0 \\
\hline
\end{tabular}


TABLE 8. Definitions for categorical variables used in final model building to predict cetacean bycatch rates.

\begin{tabular}{|c|c|c|c|}
\hline Variables $^{1}$ & Pilot whale species & White-sided dolphin & Common dolphin \\
\hline VHP & $\begin{array}{l}\text { Small }<1265 \text { horse power } \\
\text { Large } \geq 1265 \text { horse power }\end{array}$ & & \\
\hline SST & & $\begin{array}{l}\text { Low }<4.44^{\circ} \mathrm{C} \\
>4.44^{\circ} \mathrm{Mid} \leq 6.49^{\circ} \mathrm{C} \\
\text { High }>6.49^{\circ} \mathrm{C}\end{array}$ & \\
\hline Depth & $\begin{array}{l}\text { Shallow }<144.07 \text { meters } \\
144.07 \geq \text { Mid }<162.58 \\
\text { Deep } \geq 162.58\end{array}$ & $\begin{array}{l}\text { Shallow } \leq 142.59 \text { meters } \\
\text { Deep }>142.59\end{array}$ & \\
\hline Slope & $\begin{array}{l}\text { Shallow } \leq 3.915^{\circ} \\
\text { Steep }>3.915^{\circ}\end{array}$ & & $\begin{array}{l}\text { Shallow } \leq 0.96^{\circ} \\
\text { Steep }>0.96^{\circ}\end{array}$ \\
\hline Month & & $\begin{array}{l}\text { Winter (March \& April) } \\
\text { Other (all other months) }\end{array}$ & \\
\hline Region $^{2}$ & $\begin{array}{l}\text { Northeast } \\
\text { Mid-Atlantic }\end{array}$ & & \\
\hline Area $^{3}$ & & $\begin{array}{l}\text { OFFEGB (statistical areas 515, } 522 \\
\text { and 561) } \\
\text { GOM (statistical areas 513, } 514 \text { and } \\
521 \text { ) } \\
\text { OTH (all other statistical areas) }\end{array}$ & $\begin{array}{l}\text { MAS (statistical areas } 622 \text { and 627) } \\
\text { SGB (statistical area 525) } \\
\text { OTH (statistical areas 515, } 537 \text { and } \\
616 \text { ) } \\
\text { MIS (all other statistical areas) }\end{array}$ \\
\hline State & & & $\begin{array}{l}\text { MAS (Connecticut, New Jersey and } \\
\text { Rhode Island) } \\
\text { OTH (all other states) }\end{array}$ \\
\hline Latitude & & & $\begin{array}{l}\text { Gulf of Maine }\left(\geq 42^{\circ}\right) \\
\text { Southern New England/Georges Bank } \\
\left(\geq 40^{\circ} \text { to }>42^{\circ}\right) \\
\text { Mid-Atlantic }\left(<40^{\circ}\right)\end{array}$ \\
\hline Fish species & $\begin{array}{l}\text { SQ (Illex and Loligo Squid) } \\
\text { OTH (all other species) }\end{array}$ & $\begin{array}{l}\text { MIX (Haddock, Monkfish, Hake } \\
\text { species, Witch Flounder, Lobster) } \\
\text { OTH (all other fish species) }\end{array}$ & $\begin{array}{l}\text { SQ (Illex and Loligo Squid) } \\
\text { MIX (Yellowtail Flounder, Mixed } \\
\text { Groundfish and Monkfish) } \\
\text { OTH (all other fish species) }\end{array}$ \\
\hline
\end{tabular}

1 See Table 1 for descriptions

2 See Fig. 2 for Management Regions

3 See Fig. 3 for Statistical Areas

TABLE 9. Summary of observed bycatch, sampled effort (pooled over years), mean annual effort and percent coverage within the strata selected to predict pilot whale species bycatch rates: Northeast and Mid-Atlantic regions (Fig. 2); Shallow depth $<144.07$; $\geq 144.07 \mathrm{Mid}<162.58$; and Deep $\geq 162.58$ meters.

\begin{tabular}{lccccc}
\hline \hline Region & Depth & $\begin{array}{c}\text { Number of } \\
\text { bycaught animals } \\
\text { observed }\end{array}$ & $\begin{array}{c}\text { Sampled bottom trawl } \\
\text { effort (days fished) } \\
\text { from 2000-2005 }\end{array}$ & $\begin{array}{c}\text { Mean (2000-2005) } \\
\text { bottom trawl effort } \\
\text { (days fished) }\end{array}$ & $\begin{array}{c}\text { Effort } \\
\text { sampled }\end{array}$ \\
\hline Northeast & Shallow & 1 & 3598 & 8622 & $42 \%$ \\
Northeast & Mid & 3 & 609 & 2045 & $30 \%$ \\
Northeast & Deep & 2 & 2224 & 4884 & $45 \%$ \\
Mid-Atlantic & Shallow & 0 & 619 & 6958 & $9 \%$ \\
Mid-Atlantic & Mid & 4 & 55 & 599 & $9 \%$ \\
Mid-Atlantic & Deep & 2 & 149 & 755 & $20 \%$ \\
\hline
\end{tabular}




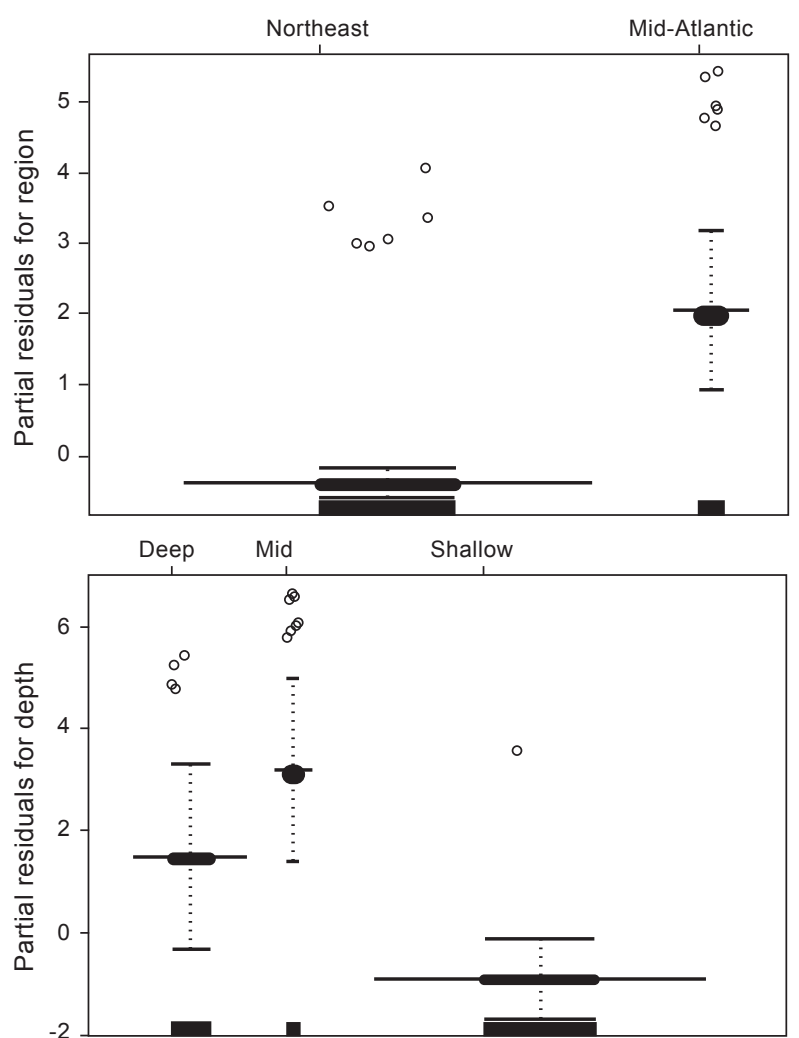

Fig. 4. The fit of pilot whale spp. takes to region and depth categories (Tables 7 and 8). The horizontal line indicates the fit where the length is a function of the number of observations in the category. The vertical lines are two standard error bands. The SE bands for the Northeast region are present with upper and lower bounds near zero but are not distinguishable in the graph due to the very large number of zeros relative to the total number of observations in this category. The jittered black circles are the partial deviance residuals for all observations. Solid black bars or 'rug plot' on the $x$-axis represent sample sizes at each category (Splus 6.2).

Relative to the null model AIC (975), the best predictors for white-sided dolphin takes were the following categorical variables: SST $(\mathrm{AIC}=884)$, month $($ AIC $=889)$, depth $($ AIC $=904)$, area $($ AIC $=908)$ and fshgrp (AIC $=922$; Table 4$)$. Month and SST were correlated $(r=0.59)$ so including them both in final modeling building was redundant. The best fitting model chosen included SST and depth $(\mathrm{AIC}=850$; Table 7). The model that also included area and fshgrp had a lower AIC score, however, residual analysis showed that this model did not predict takes well for specific areas and fish groups, thus leading to larger residuals when compared to a simpler model. As a result, the final GLM log-linear predic-

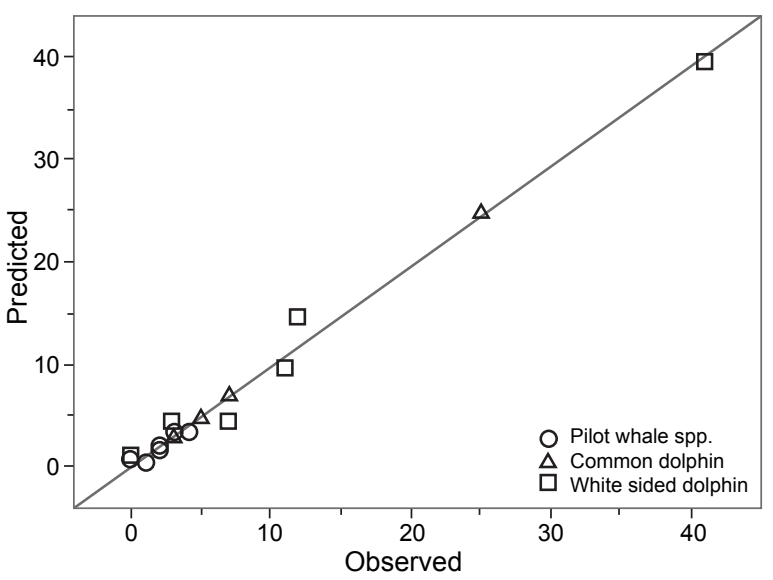

Fig. 5. Linear plot indicating model GOF by comparing the final GLM model predicted takes to observed takes by species and strata defined by final model covariates (Tables 6, 8, 10, and 12). Diagonal line indicates a 1:1 relationship between the predicted and actual bycatch estimates.

tor for predicting white-sided dolphin bycatch rates is defined as:

White-sidedDolphinTakes/DaysFished $=\exp (-4.436+$ 1.161 LowSST + 0.201 MidSST - 0.869 ShallowDepth)

where SST is defined by three categories (lowSST is $\leq 4.44^{\circ} \mathrm{C}$; MidSST is $4.44-6.49^{\circ} \mathrm{C}$; and high is $>6.49^{\circ} \mathrm{C}$ ), and depth is defined by two categories (ShallowDepth is $\leq 142.59 \mathrm{~m}$; and DeepDepth is $>142.59 \mathrm{~m}$; Table 8). The predicted number of bycaught white-sided dolphin as compared to the observed bycatch indicated the model fit well (Fig. 5).

The estimated bycatch rates for the six different strata ranged from a low of $0.00127(\mathrm{CV}=0.16)$ animals per day fished in shallow waters with high SST to a high bycatch rate of $0.07377(\mathrm{CV}=0.40)$ animals per day fished in deep waters with low SST. In general the bycatch rates are higher in deep waters than in shallow waters, and the bycatch rates decrease as SST increases (Table 10; Fig. 6). The larger SE's for the low SST range is probably due to the small amount of fishery effort and resultant low observer sampling in low SST waters relative to the other SST ranges (Fig. 6; Table 11).

Less than $5 \%$ of the fishing effort on average, over both regions, took place in the stratum with the highest bycatch rate (deep water/low SST), whereas $37 \%$ of the effort on average took place in the stratum with the lowest bycatch rate (shallow water /high SST; Table 11). 


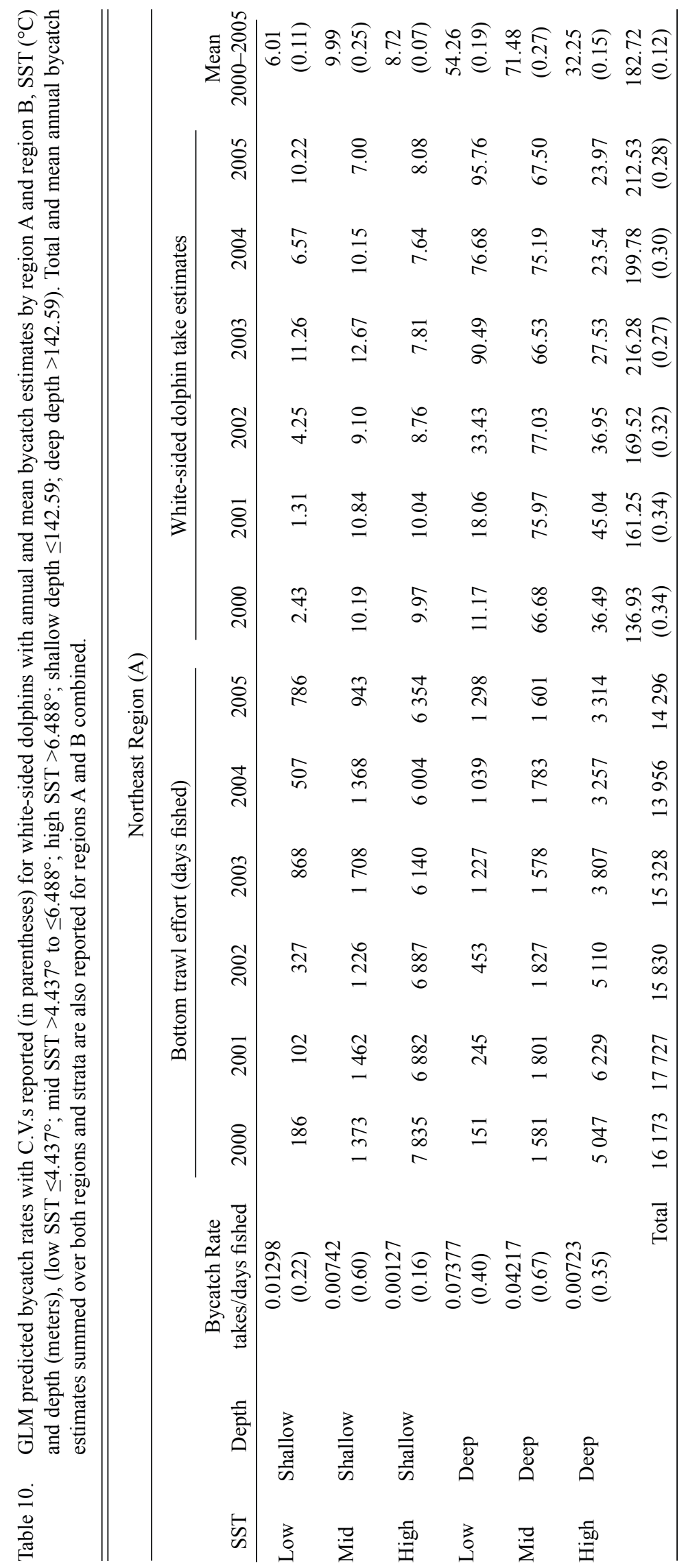


ROSSMAN: Bycatch of Small Cetaceans

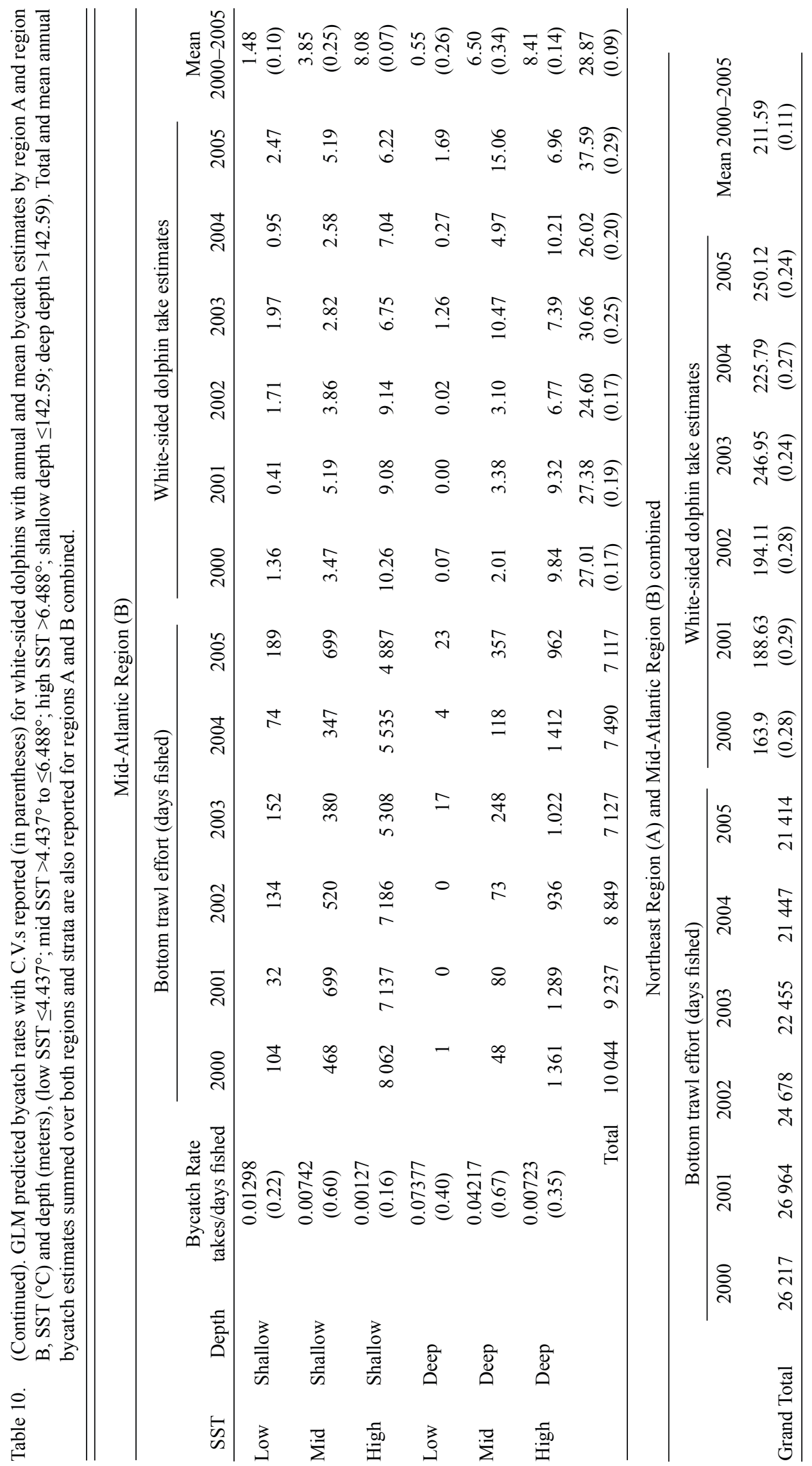




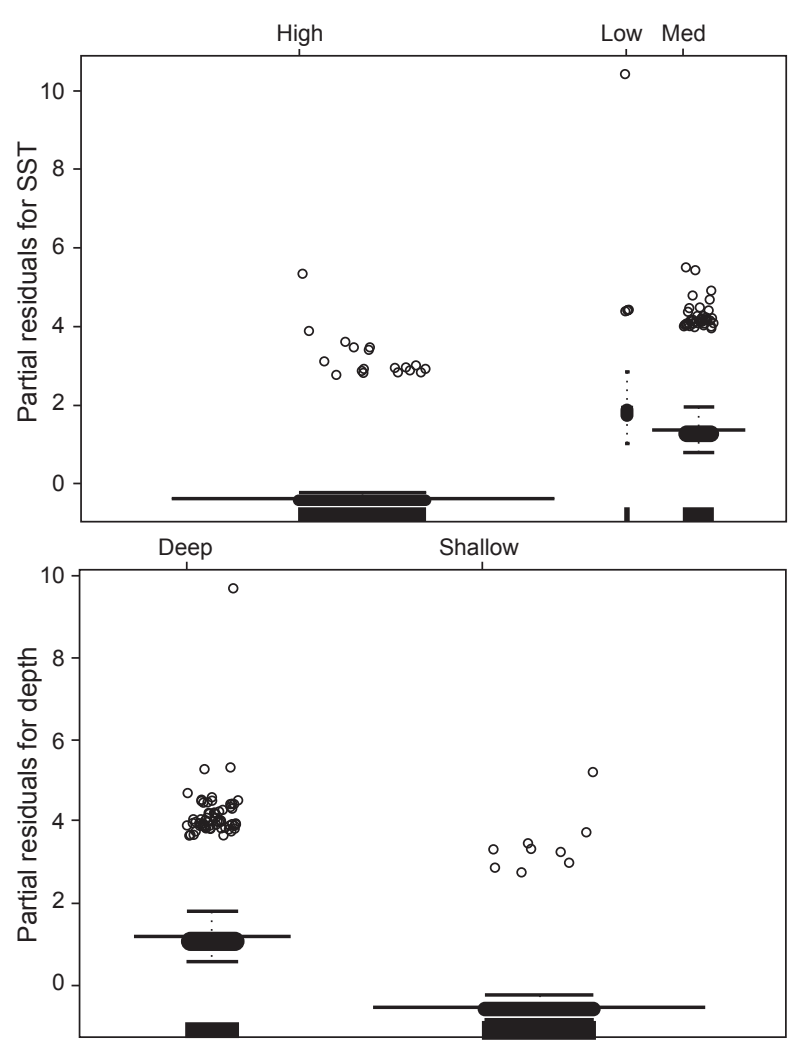

Fig. 6. The fit of white-sided dolphin takes to the SST and Depth categories (Tables 7 and 8). The horizontal line indicates the fit where the length is a function of the number of observations in the category. The vertical lines are two standard error bands. The SE bands for the high SST category are present with upper and lower bounds near zero but are not distinguishable in the graph due to the very large number of zeros relative to the total number of observations in this category. The jittered black circles are the partial deviance residuals for all observations. Solid black bars or 'rug plot' on the $x$-axis represent sample sizes at each category (Splus 6.2).
Common dolphin. Total mean annual bycatch estimates of common dolphin from 2000-2005 over both regions and all strata was $142(\mathrm{CV}=0.10)$ animals (Table 12). On average, over both regions, more than half of the bycatch $(58 \%)$ came from vessels fishing in the MAS area followed by the OTH $(30 \%)$, where the remaining $12 \%$ of bycatch came from the SGB and MIS areas (Table 12). Definition of areas are in Table 8.

Relative to the null model AIC (601), the best predictors for common dolphin bycatch were the following categorical variables: area $(\mathrm{AIC}=455)$, fshgrp $(\mathrm{AIC}=465)$, state $(\mathrm{AIC}=483)$, latitude $(\mathrm{AIC}=519)$ and slope $(\mathrm{AIC}=518$; Table 5). Models with area included had the lowest AIC's. However, as additional variables were added to area the parameter ratio's decreased (Table 7). As a result, the simplest model that included only area (AIC $=455$ ) was selected as the best fitting model to predict common dolphin bycatch rates (Table 6). Thus, the final GLM log-linear predictor for predicting common dolphin bycatch rates is defined as:

$$
\begin{gathered}
\text { CommonDolphin/DaysFished }=\exp (-4.844- \\
2.780(M I S)+0.036(O T H)-0.182(S G B))
\end{gathered}
$$

where area is defined by four categories ( $M A S, M I S$, $O T H$, and $S G B$; Table 8$)$. The highest bycatch rate was in the MAS area (Fig. 7). The larger SE for the MAS area is probably due to the small amount of fishery effort and resultant low observer sampling in the MAS area relative to the other areas (Fig. 7; Table 13). The predicted number of bycaught common dolphin as compared to the observed takes demonstrates a perfect fit to the raw data (Fig. 5).

The estimated bycatch rates range from a low of $0.00056(\mathrm{CV}=0.61)$ animals per day fished in the MIS areas to a high of $0.14708(\mathrm{CV}=0.35)$ animals per day fished in the MAS areas (Table 12).

TABLE 11. Summary of observed bycatch, sampled effort (pooled over years), mean annual effort and percent coverage within the strata selected to predict white-sided dolphin bycatch rates: Low $\mathrm{SST} \leq 4.437^{\circ} \mathrm{C}$; mid $\mathrm{SST}>4.437^{\circ} \mathrm{C}$ to $\leq 6.488^{\circ} \mathrm{C}$; high $\mathrm{SST}>6.488^{\circ} \mathrm{C}$; shallow depth $\leq 142.59$; deep depth $>142.59$ meters.

\begin{tabular}{lccccc}
\hline \hline SST & Depth & $\begin{array}{c}\text { Number of } \\
\text { bycaught animals } \\
\text { observed }\end{array}$ & $\begin{array}{c}\text { Sampled bottom trawl } \\
\text { effort (days fished) from } \\
2000-2005\end{array}$ & $\begin{array}{c}\text { Mean (2000-2005) } \\
\text { bottom trawl effort } \\
\text { (days fished) }\end{array}$ & $\begin{array}{c}\text { Effort } \\
\text { sampled }\end{array}$ \\
\hline Low & Shallow & 0 & 94 & 577 & $16 \%$ \\
Mid & Shallow & 3 & 583 & 1865 & $31 \%$ \\
High & Shallow & 7 & 3496 & 6352 & $55 \%$ \\
Low & Deep & 11 & 132 & 720 & $18 \%$ \\
Mid & Deep & 41 & 941 & 1849 & $51 \%$ \\
High & Deep & 12 & 2012 & 5624 & $36 \%$ \\
\hline
\end{tabular}


ROSSMAN: Bycatch of Small Cetaceans

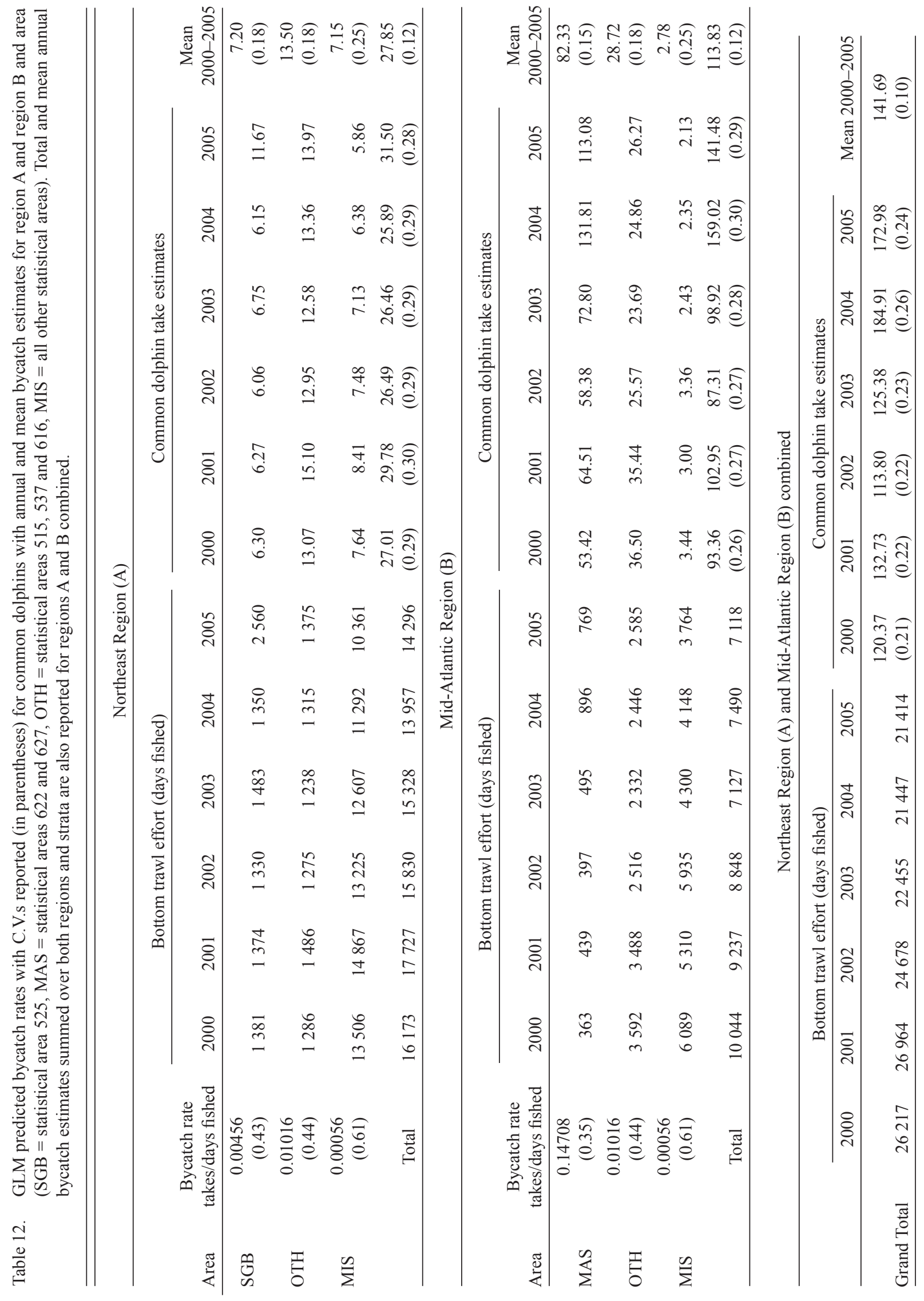


TABLE 13. Summary of observed bycatch, total effort and sampling coverage within the strata selected to predict common dolphin bycatch rates. SGB $=$ statistical area 525; MAS = statistical areas 622 and 627; OTH = statistical areas 515, 537 and 616; MIS = all other statistical areas (Fig. 3).

\begin{tabular}{lcccc}
\hline \hline Area & $\begin{array}{c}\text { Number of } \\
\text { bycaught animals } \\
\text { observed }\end{array}$ & $\begin{array}{c}\text { Sampled bottom trawl } \\
\text { effort (days fished) from } \\
2000-2005\end{array}$ & $\begin{array}{c}\text { Mean (2000-2005) } \\
\text { bottom trawl effort } \\
\text { (days fished ) }\end{array}$ & $\begin{array}{c}\text { Effort } \\
\text { sampled }\end{array}$ \\
\hline MAS & 25 & 163 & 560 & $29 \%$ \\
MIS & 3 & 5306 & 17567 & $30 \%$ \\
OTH & 7 & 689 & 4156 & $17 \%$ \\
SGB & 5 & 1097 & 1580 & $69 \%$ \\
\hline
\end{tabular}

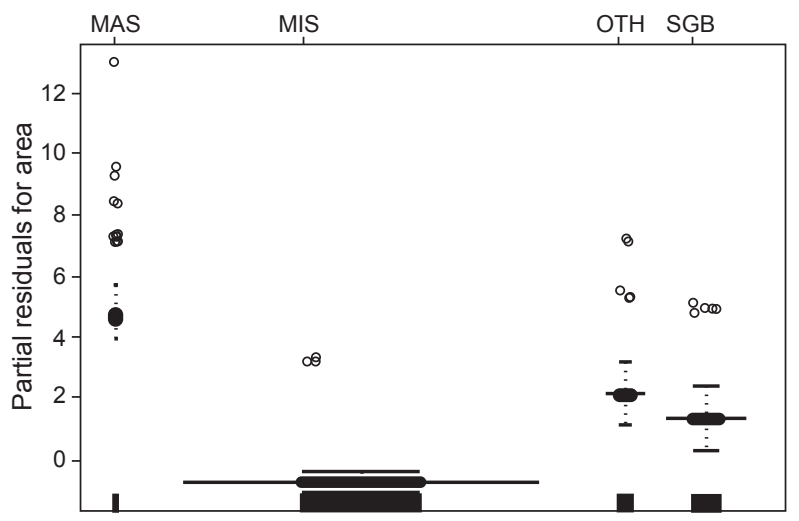

Fig. 7. The fit of common dolphin takes to area categories (Tables 7 and 8). The horizontal line indicates the fit where the length is a function of the number of observations in the category. The vertical lines are two standard error bands. The jittered black circles are the partial deviance residuals for all observations. Solid black bars or 'rug plot' on the $x$-axis represent sample sizes at each category (Splus 6.2).

Less than $5 \%$ of the mean annual effort over both regions took place in the areas with the highest bycatch rate (MAS), whereas $74 \%$ of the mean annual effort, over both regions, took place in the areas with the lowest bycatch rate (MIS; Table 13).

\section{Dispersion investigation}

Raw observed white-sided and common dolphin takes (i.e., not accounting for any covariates) showed some degree of over-dispersion (Table 2). Conversely, raw pilot whale takes fit the Poisson distribution.

During the univariate GLM analysis phase, for all three cetacean species, dispersion varied by type of covariate (Tables 2-5). All of the univariate pilot whale models were under-dispersed (not to a large degree in most cases) compared to the white-sided and common dolphin univariate models. The common dolphin univariate models showed the largest degree of over-dispersion, though all dispersion values were less than three.

During the multi-variable model building phase, dispersion decreased as covariates were added in the common dolphin model, while dispersion increased slightly as covariates were added in the pilot whales and whitesided dolphin models, though dispersion values of all the final models were less than two (Table 7).

\section{Other modeling frameworks}

ZIP models assume that there are two types of bottom trawl tows that end up without observed bycatch: (1) tows that could have had a bycatch event, but by chance did not (for example, a bycatch event could have been observed if they fish longer), and (2) tows that are likely to never have a bycatch event. ZIP models did not account for additional variability over that accounted for in the quasi-Poisson GLM models. This could be due to the very low probability of observing multiple animals in one tow. A quasi-binomial GLM was also explored for pilot whales, since tows had either zero or one take. However, the goodness-of-fit for the quasi-binomial did not improve the fit as compared to the quasi-Poisson GLM model.

\section{Bycatch relative to $P B R$}

In conclusion, the mean (2000-2005) annual bycatch of pilot whales, white-sided dolphin and common dolphin attributed to bottom trawl fishing gear is $72(\mathrm{CV}=0.13), 212(\mathrm{CV}=0.11)$ and $142(\mathrm{CV}=0.10)$ animals, respectively. Presently, these mean annual take estimates are at $29 \%, 42 \%$ and $14 \%$ of their respective stocks potential biological removal (PBR; Waring et al., 2007). 


\section{Discussion}

The cetacean GLM models had low but varying degrees of dispersion implying these data are not truly under or over-dispersed (Table 7). The model building process indicates that there is enough heterogeneity in the characteristics among bottom trawl tows that the right combination of covariates can remedy the dispersion problem (Cameron and Trivedi, 1998). However, further analysis of the pilot whale data is needed to determine whether these data exhibit apparent or true under-dispersion. There may be some other mechanism related to the bycatch of cetaceans that has not been discovered or captured by the covariates, or it could be real negative contagion, which is the occurrence of one event decreasing the probability of future events (King, 1989). For example, when an animal is captured there could be a behavioral mechanism among cetaceans traveling in groups that decreases the likelihood of another bycatch event. Sighting logs from observed trips often note the presence of several animals in the vicinity when an incidental take has occurred. It is also common to observe groups of animals present around bottom trawl vessels during standard trawling operations (setting, towing and hauling of gear) when no takes have occurred.

In general, among all three bycatch rate models, spatial (region, area and latitude), habitat or environment (slope, depth or SST), and fishing practices (fshgrp) variables were significant and had the lowest AIC scores (Tables 3-5). The type of fish harvested (fshgrp) in particular was among the lowest AIC scores for all three cetacean species, followed by habitat and spatial variables (depth, SST and area; Table 7). These variables are associated with each other to some degree. For example, chisquare tests of independence show that area fished and target species $\left(f_{s h g r p}\right)$ are highly associated. In addition, target fish species and area were associated with habitat characteristics such as depth and slope. Hence, the models that fit appear to be describing features preferred by cetaceans for various reasons (e.g., feeding, mating, socializing) that also coincide with features preferred by fishermen when harvesting specific species (Fertl and Leatherwood, 1997; Garrison, 2007). Because the bycatch of cetaceans is rare there isn't enough power in the data to support the addition of all these potentially important features. However, the final models selected for each cetacean species fit the data, indicating that these models are appropriate statistical predictive models, even if they are not describing a mechanistic relationship (i.e., cause-and-effectrelationship).However, McCracken (MS 2004) also notes that development of methods to handle rare events observed in hierarchical data could lead to improvements in model selection.
The estimated bycatch rates are also known as ratio estimators in the sense that the models are predicting take per unit of effort. One of the assumptions for valid use of a ratio estimator is that there needs to be a linear correlation between $x$ and $y$ (in this case bycatch and days fished, respectively). Significant relationships between bycatch and days fished were present within some of the strata defined by the model covariates for all three species. The lack of association in some strata is likely due to the sparse number of bycaught animals and may add bias to the estimated bycatch rates for these species (Tables 9, 11 and 13). McCracken (MS 2004) found traditional models to be adequate in predicting bycatch of rare events.

A noticeable pattern in the diagnostic plots is the small sample sizes in several strata. This is not due to poor sampling but rather low commercial fishing effort relative to the other strata (Tables 9, 11 and 13). Some of the strata with low effort are associated with a high abundance of animals. As a result, these particular areas have the highest take rate per unit of effort. The highest bycatch rates were found in deep waters with low SST (white-sided dolphin) or where vessels in the Mid-Atlantic region fished in mid to deep waters (pilot whales) or in offshore Statistical Areas in the Mid-Atlantic region (common dolphin; Fig. 3).

Future improvements to model development may include the removal of areas from the analyses where probability of takes is zero, for example in time/areas where there is no fishing or no cetaceans. This may improve model fitting and remove negative bias. For example, white-sided dolphin have not been sighted south of the Delmarva Peninsula and pilot whales have not been sighted on the shelf habitat (Palka et al., 1997; Department of the Navy, 2005).

The purpose of the models reviewed in this paper was to estimate bycatch rates attributable to bottom trawl fishing gear. Under different objectives, such as, mitigation or developing a model of the mechanistic reasons for bycatch, different models may be preferred. The NEFOP dataset contains many vessel and gear characteristics not investigated in this analysis because those characteristics are not known for the entire fishery which would not allow expanding a bycatch rate to a total bycatch estimate. These other characteristics could be investigated further to learn more about statistical correlations between gear characteristics and bycatch or about potential mechanisms that entrap animals in bottom trawl nets. A potentially important variable not collected in any dataset is when the takes occur; did the take occur at depth or near the surface. Hamer and Goldsworthy (2006) documented 
an increased numbers of Australian fur seals at sub-surface levels during net deployment and retrieval relative to the number of animals present at the surface suggesting that the animals dive to forage on fish in the net near the surface. Increased use of video technology should be utilized as a research tool to learn more about factors associated with small cetacean bycatch that cannot be observed from the deck of a trawl vessel.

The high abundance of whales and dolphins in fishing areas on the Northeast U.S. continental shelf and the fact that these animals have been observed swimming in and out of the trawls, in comparison to the rareness of bycatch suggests that there may be some other causal factors that increase the risk of animal(s) and gear interacting. One theory discussed among fishermen and scientists involves the collapsing of the mouth of the trawl net when tow speed is reduced to commence hauling operations or turning of the vessel, and how this may trap animals that may be depredating on fish inside the body of the trawl net while it is actively being towed through the water column (Morizur et al., 1999; Smith and Baird, MS 2005; Du Fresne et al., 2007; NOAA, 2009). Another theory is that animals are attracted to the acoustic sound emitted while setting or hauling the trawl net. Discussions on behavioral and mechanical processes which include social and feeding behavior, vessel processes, and gear characteristic that could contribute to the risk of interaction have been discussed in Corkeron et al. (1990), Fertl and Leatherwood (1997), Pace et al. (2003), Read (2005) and Waring et al. (1990).

Since Fertl and Leatherwood (1997) was issued, interactions of cetaceans and pinnipeds with midwater trawls continue to dominate the literature. Du Fresne et al. (2007) also note that interactions between cetaceans and trawls in most of the world is attributed to mid-water trawls due to a variety of factors. However, it is important to note that this is not the case in the NWA region of the U.S. The results of this study show that mean mortality of white-sided dolphin and pilot whales attributed to bottom trawl fishing are three times larger than bycatch in mid-water trawls (Waring et al., 2007). This is largely due to differences in timing and spatial location (on the continental shelf) of the pelagic Clupea harengus and Scomber scombrus fisheries in relation to presence of small cetaceans (NMFS-NEFSC 2009). In contrast, bottom trawl fisheries in the NWA U.S. occur year round in regions that overlap with the preferred habitat of whitesided dolphin, pilot whales and common dolphin (Payne and Heinemann, 1993; Gannon et al., 1997; Orphanides and Magnusson, 2007; Waring et al., 2007).
One final important note to be made pertains to the assumption that effort from VTR's used to expand estimated bycatch rates represent an accurate (unbiased) total estimate of effort. It can be argued that self-reported catch data will inherently contain some degree of bias. However, in the Northeast region of the U.S. Rago et al. (2005) states that there is close agreement between landings reported on VTR's and dealer reported landings which are considered a near census of total landings. The dealer reported landings however do not contain total effort as this parameter is only reported on VTR's. In addition, Rago et al. (2005) evaluated accuracy of observed catches for estimating finfish discards by comparing average catches, trip duration and spatial coherence of trips with and without observers on board. Overall, results show strong similarities between data recorded on VTR's and independent observer reports in the Northeast region. It should be noted that analyses presented by Rago et al. (2005) rely heavily on landings of Northeast multi-species groundfish. Other important fisheries in the mid-Atlantic region that also interact with small cetaceans (i.e., Loligo and Illex squid) were not evaluated for accuracy. However, several of the primary mid-Atlantic fisheries that interact with the small cetaceans addressed in this paper are managed by federal fishery management plans that have the same mandatory reporting requirements as the Northeast multi-species groundfish fisheries. As a result, it was assumed that VTR's provide and accurate (unbiased) representation of total bottom trawl fishing effort across both the Northeast region and MidAtlantic regions.

\section{Acknowledgements}

I would especially like to thank Chris Orphanides for acquiring all the environmental data that turned out to be quite important in predicting the bycatch of cetaceans. I am also grateful to my colleagues Heather Haas and Richard Merrick for providing very helpful comments on the early drafts of the manuscript. Thank you to Debi Palka for providing further scientific and editorial comments for the final draft. Finally, I would also like to thank all the fisheries observers for their efforts in collecting high quality data and the NEFOP staff for their unwavering dedication to the program.

\section{References}

ABEND, A., and T. D. SMITH. MS 1999. Review of distribution of the long-finned pilot whale (Globicephala melas) in the North Atlantic and Mediteranean. U.S. Dep. Commer., NOAA Tech. Memo., NMFS-NE-117.

BURNHAM, K. P., and D. R. ANDERSON. 2002. Model Selection and Multimodel Inference: a Practical Informa- 
tion-Theoretic Approach, $2^{\text {nd }}$ edition. Springer-Verlag, New York, 488 p.

CAMERON, A. C., and P. K. TRIVEDI. 1998. Regression analysis of count data. Econ. Soc. Monogr., No. 30, $436 \mathrm{p}$.

CORKERON, P. J., M. M. BRYDEN, and K. E. HEDSRTROM. 1990. The Bottlenose Dolphin. Academic Press, Inc., San Diego.

COUPERUS, A. S. 1997. Interactions between Dutch midwater trawl and Atlantic white-sided dolphins (Lagenorhynchus acutus) southwest of Ireland. J. Northw. Atl. Fish. Sci., 22: 209-218. doi:10.2960/J.v22.a16

DEPARTMENT OF THE NAVY. 2005. Marine resource assessment for the Northeast Operating Areas: Atlantic City, Narragansett Bay, and Boston. Naval Facilities Engineering Command, Atlantic; Norfolk, Virginia. Contract Number N62470-02-D-9997, Task Order Number 0018. Prepared by Geo-Marine, Inc., Newport News, Virginia.

DU FRESNE, S., A. R. GRANT, W. S. NORDEN, and J. H. PIERRE. 2007. Factors affecting cetacean bycatch in a New Zealand trawl fishery. DOC Research \& Development Series 282, Department of Conservation, Wellington, $18 \mathrm{p}$. http://www.doc.govt.nz/upload/documents/ science-and-technical/drds282.pdf

EFRON, B., and R. J. TIBSHIRANI. 1993. An Introduction to the Bootstrap. Chapman and Hall, 436 p.

FEDERAL REGISTER. 2007. List of Fisheries 2008. 50 CFR Part 229. Vol. 72, No. 227, November 27, 2007.

FERTL, D., and S. LEATHERWOOD. 1997. Cetacean Interactions with Trawls: A Preliminary Review. J. Northw. Atl. Fish. Sci., 22: 219-248. doi:10.2960/J.v22.a17

GANNON, D. P., A. J. READ, J. E. CRADDOCK, K. M. FRISTRUP, and J. R. NICOLAS. 1997. Feeding ecology of long-finned pilot whales Globicephala melas in the western North Atlantic. Mar. Ecol. Prog. Ser., 148: 1-10. doi:10.3354/meps 148001

GARRISON, L. P. 2007. Interactions between marine mammals and pelagic longline fishing gear in the U.S. Atlantic Ocean between 1992 and 2004. Fish. Bull., 105: 408-417.

HAMER, D. J., and S. D. GOLDSWORTHY. 2006: Sealfishery operational interactions: identifying the environmental and operational aspects of a trawl fishery that contribute to by-catch and mortality of Australian fur seals (Arctocephalus pusillus doriferus). Biol. Conserv., 130: 517-529. doi:10.1016/j.biocon.2006.01.014

HARRELL F. E, K. L. LEE, R. M. CALIFF, D. B. PRYOR, and R. A. ROSATI. 1984. Regression modeling strategies for improved prognostic prediction. Stat. Med., 3: 143-152. doi:10.1002/sim.4780030207

KING, G. 1989. Variance specification in event count models: from restrictive assumptions to a generalized estimator. Am. J. Polit. Sci., 33: 762-784. doi:10.2307/2111071

KENNEY, R. D., and H. E. WINN. 1986. Cetacean high-use habitats of the northeastern United States continental shelf. Fish. Bull., 84: 345-357.

MCCRACKEN, M. L. MS 2004. Modeling a very rare event to estimate sea turtle bycatch: lessons learned. US Dep.
Commer., NOAA Tech Memo., NOAA-TM-NMFS-PIF$\mathrm{SC}-3 ; 25 \mathrm{p}$.

MILLER, T. J., and J. R. SKALSKI. 2006. Estimation of seabird bycatch for North Pacific longline vessels using design- and model-based methods. Can. J. Fish. Aquat. Sci., 63: 1878-1889. doi:10.1139/F06-075

MORIZUR, Y., S. D. BERROW, N. J. C. TREGENZA, A. S. COUPERUS, and S. POUVREAU. 1999: Incidental catches of marine mammals in pelagic trawl fisheries of the northeast Atlantic. Fish. Res., 41: 297-307. doi:10.1016/S0165-7836(99)00013-2

MURRAY, K. T. 2008. Estimated average annual bycatch of loggerhead sea turtles (Caretta caretta) in US Mid-Atlantic bottom otter trawl gear, 1996-2004 ( $2^{\text {nd }}$ edition). Northeast Fish. Sci. Cent. Ref. Doc., 08-20, 32 p.

NMFS. 1999. Our Living Oceans. Report on the status of U.S. living marine resources, 1999. U.S. Dep. Commer., NOAA Tech. Memo., NMFS-F/SPO-41, on-line version, http://spo.nwr.noaa.gov/olo99.htm

2004. Evaluating Bycatch: A National Approach to Standardized Bycatch Monitoring Programs. U.S. Dep. Commer., NOAA Tech. Memo., NMFS-F/SPO-66, 108 p. On-line version, http://spo.nmfs.noaa.gov/tm

NMFS-NEFSC. 2008. Fisheries Sampling Branch, Fisheries Observer Program Manual. National Marine Fisheries Service-Northeast Fisheries Science Center, http:// www.nefsc.noaa.gov/femad/fishsamp/fsb, accessed on 9/24/2008.

2009. Status of Fishery Resources off the Northeastern United States. http://www.nefsc.noaa.gov/sos/species; accessed on 6/16/2009.

NMFS-NERO. 2008a. Fishery management plans. National Marine Fisheries Service-Northeast Regional Office, http://www.nero.noaa.gov/nero/fishermen/regs.html, accessed on $9 / 24 / 2008$.

2008b. Vessel Trip Report Instructions. National Marine Fisheries Service-Northeast Regional Office, http:// www.nero.noaa.gov/ro/fso/vtr_inst.pdf, accessed on 9/24/2008.

NOAA FISHERIES. 2009. Reducing Marine Mammal Interactions in Atlantic Trawl Fisheries. Education and Outreach Guide developed for the Atlantic Trawl Gear Take Reduction Team in cooperation with Garden State Seafood Association.

ORPHANIDES, C. D., and G. M. MAGNUSSON. 2007. Characterization of the Northeast and Mid-Atlantic Bottom and Mid-water Trawl Fisheries Based on Vessel Trip Report (VTR) Data. U.S. Dep. Commer., Northeast Fish. Sci. Cent. Ref. Doc. 07-15, 127 p.

PACE, D. S., M. PULCINI, and F. TRIOSSI. 2003. Interactions with Fisheries: Modalities of Opportunistic Feeding for Bottlenose Dolphins at Lampedusa Island. Proceedings of the $17^{\text {th }}$ Annual Conference of the European Cetacean Society (Las Palmas de Gran Canaria, Spain, 9-13 March 2003).

PALKA, D., A. READ, and C. POTTER. 1997. Summary of knowledge of white-sided dolphins (Lagenorhynchus acutus) from US and Canadian Atlantic waters. Rep. Int. Whal. Comm., 47: 729-734. 
PAYNE, P. M., and D. W. HEINEMANN. 1993. The distribution of pilot whales (Globicephala sp.) in shelf and shelfedge waters of the northeastern United States, 1987-1998. In: Donovan, G.P.; Lockyer, C. H.; Martin, A.R., (eds.). Biology of the Northern Hemisphere Pilot Whales. Rep. Int. Whal. Comm. (Special Issue), 14: 51-58.

RAGO, P., S. E. WIGLEY, and M. FOGARTY. 2005. NEFSC Bycatch Estimation Methodology: Allocation, Precision, and Accuracy. U.S. Dep. Commer., Northeast Fish. Sci. Cent. Ref. Doc. 05-09; 44 p.

READ, A. J. 2005. By-Catch and depredation. In: T. J. Ragen, J. E. Reynolds, W. F. Perrin, R. R. Reeves, and S. Montgomery (eds.). Marine Mammal Research: Conservation beyond Crisis. The John Hopkins University Press, Baltimore, Maryland, $223 \mathrm{p}$.

SMITH, M. H., and S. J. BAIRD. MS 2005: Factors that may influence the level of incidental mortality of New Zealand sea lions (Phocarctos hookeri) in the squid (Nototodarus spp.) trawl fishery in SQU 6T. New Zealand Fisheries Assessment Report 2005/20. Ministry of Fisheries, Wellington, New Zealand, $35 \mathrm{p}$.

STEVENSON D., L. CHIARELLA, D. STEPHAN, R. REID, K. WILHELM, J. MCCARTHY, and M. PETONY. 2004. Characterization of The Fishing Practices and Marine Benthic Ecosystems of the Northeast U.S. Shelf, and an evaluation of the Potential Effects of Fishing on Essential Fish Habitat. NOAA Tech. Memo., NMFS-NE-181, $179 \mathrm{p}$.
STOKES M. E., C. S. CHARLES, and G. G. KOCH. 1995. Categorical Data Analysis Using the SAS System, Cary N.C: SAS Institute Inc, 499 p.

TREGENZA, N .J. C., and A. COLLET. 1998. Common dolphin Delphinus delphis bycatch in pelagic trawl and other fisheries in the North East Atlantic. Rep. Int. Whal. Comm., 48: 453-459.

WADE, P. R., and R. ANGLISS. 1997. Guidelines for assessing marine mammal stocks: Report of the GAMMS workshop April 3-5, 1996, Seattle, Washington. NOAA Tech. Memo., NMFS-OPR-12, 93 p.

WARDEN, M. L., and C. D. ORPHANIDES. 2008. Preparation of the Northeast Fisheries Observer Program gillnet data for use in bycatch analyses of protected species. US Dept. Comm., Northeast Fish. Sci. Cent. Ref. Doc. 08-17; $44 \mathrm{p}$.

WARING, G. T., P. GERRIOR, P. M. PAYNE, B. C. PARRY, and J. R. NICOLAS. 1990. Incidental take of marine mammals in foreign fishing activities off the northeast United States, 1977-88. Fish. Bull., 88: 347-360.

WARING, G. T., E. JOSEPHSON, C. P. FAIRFIELD, and K. MAZE-FOLEY. 2007. U.S. Atlantic and Gulf of Mexico marine mammal stock assessments - 2007. NOAA Tech. Memo., NMFS-NE-205, 415 p.

WATSON, J. W., S. P. EPPERLY, A. K. SHAH, and D. G. FOSTER. 2005. Fishing methods to reduce sea turtle mortality associated with pelagic longlines. Can. J. Fish. Aquat. Sci., 62: 965-981. doi:10.1139/f05-004 
ROSSMAN: Bycatch of Small Cetaceans

APPENDIX 1. Total number of bottom trawl trips and percent sampled by sub-region, statistical area, and year (Gulf of Maine $=$ GOM; Georges Bank = GB; Southern New England = SNE; Northern mid-Atlantic $=$ NMA; Southern mid-Atlantic $=$ SMA). Trips that fished in more than one statistical area were treated as separate trips. The years 2000-2005 were selected for predicting small cetacean bycatch mortality.

\begin{tabular}{|c|c|c|c|c|c|c|c|c|c|c|c|c|}
\hline $\begin{array}{l}\text { Sub- } \\
\text { region }\end{array}$ & $\begin{array}{l}\text { Stat. } \\
\text { area }\end{array}$ & 1996 & 1997 & 1998 & 1999 & 2000 & 2001 & 2002 & 2003 & 2004 & 2005 & $\begin{array}{c}\text { Mean } \\
\text { sampling } \\
\text { coverage }\end{array}$ \\
\hline \multirow[t]{14}{*}{ GOM } & \multirow{2}{*}{511} & 121 & 60 & 52 & 82 & 89 & 79 & 69 & 70 & 46 & 20 & \\
\hline & & $1.65 \%$ & $0.00 \%$ & $0.00 \%$ & $0.00 \%$ & $1.12 \%$ & $0.00 \%$ & $0.00 \%$ & $1.43 \%$ & $10.87 \%$ & $15.00 \%$ & $4.75 \%$ \\
\hline & \multirow{2}{*}{512} & 326 & 373 & 376 & 393 & 255 & 274 & 338 & 456 & 359 & 254 & \\
\hline & & $1.23 \%$ & $0.27 \%$ & $0.53 \%$ & $0.00 \%$ & $1.18 \%$ & $1.09 \%$ & $1.48 \%$ & $7.24 \%$ & $5.29 \%$ & $6.69 \%$ & $3.83 \%$ \\
\hline & \multirow{2}{*}{513} & 4855 & 3619 & 2981 & 2666 & 3326 & 3482 & 3193 & 2782 & 2630 & 2021 & \\
\hline & & $2.04 \%$ & $0.14 \%$ & $0.13 \%$ & $0.11 \%$ & $2.04 \%$ & $0.89 \%$ & $2.88 \%$ & $3.06 \%$ & $3.04 \%$ & $5.99 \%$ & $2.98 \%$ \\
\hline & \multirow{2}{*}{514} & 7747 & 6612 & 7323 & 5642 & 5987 & 6215 & 6139 & 6068 & 5443 & 5349 & \\
\hline & & $0.17 \%$ & $0.17 \%$ & $0.07 \%$ & $1.12 \%$ & $2.51 \%$ & $2.98 \%$ & $5.36 \%$ & $6.61 \%$ & $6.08 \%$ & $9.14 \%$ & $5.45 \%$ \\
\hline & \multirow{2}{*}{515} & 770 & 700 & 833 & 676 & 483 & 525 & 527 & 457 & 437 & 403 & \\
\hline & & $1.04 \%$ & $1.14 \%$ & $0.24 \%$ & $0.00 \%$ & $3.93 \%$ & $3.05 \%$ & $4.93 \%$ & $16.19 \%$ & $10.07 \%$ & $26.55 \%$ & $10.79 \%$ \\
\hline & \multirow{2}{*}{464} & & 5 & 9 & 14 & 11 & 11 & 6 & 3 & 3 & 22 & \\
\hline & & $15.38 \%$ & $20.00 \%$ & $0.00 \%$ & $0.00 \%$ & $18.18 \%$ & $9.09 \%$ & $0.00 \%$ & $100.00 \%$ & $100.00 \%$ & $100.00 \%$ & $54.54 \%$ \\
\hline & \multirow{2}{*}{465} & & 17 & 33 & 11 & 10 & 17 & 10 & 5 & 7 & 7 & \\
\hline & & $13.04 \%$ & $5.88 \%$ & $0.00 \%$ & $0.00 \%$ & $30.00 \%$ & $11.76 \%$ & $20.00 \%$ & $100.00 \%$ & $42.86 \%$ & $100.00 \%$ & $50.77 \%$ \\
\hline $\begin{array}{l}\text { Sub- } \\
\text { region }\end{array}$ & $\begin{array}{l}\text { Stat. } \\
\text { area }\end{array}$ & 1996 & 1997 & 1998 & 1999 & 2000 & 2001 & 2002 & 2003 & 2004 & 2005 & $\begin{array}{c}\text { Mean } \\
\text { sampling } \\
\text { coverage }\end{array}$ \\
\hline \multirow[t]{22}{*}{ GB } & \multirow{2}{*}{521} & 1561 & 1359 & 1236 & 1424 & 1287 & 1709 & 1513 & 1225 & 1228 & 1013 & \\
\hline & & $0.83 \%$ & $1.91 \%$ & $0.49 \%$ & $0.98 \%$ & $2.87 \%$ & $3.39 \%$ & $10.31 \%$ & $15.84 \%$ & $11.07 \%$ & $35.93 \%$ & $13.23 \%$ \\
\hline & \multirow{2}{*}{522} & 1015 & 934 & 935 & 977 & 912 & 1018 & 908 & 851 & 662 & 722 & \\
\hline & & $1.87 \%$ & $0.75 \%$ & $1.13 \%$ & 1.13 & $3.84 \%$ & $3.63 \%$ & $9.14 \%$ & $15.16 \%$ & $18.88 \%$ & $62.88 \%$ & $18.92 \%$ \\
\hline & \multirow{2}{*}{561} & 122 & 106 & 209 & 226 & 223 & 426 & 276 & 313 & 199 & 71 & \\
\hline & & $7.38 \%$ & $0.00 \%$ & $1.44 \%$ & $1.77 \%$ & $4.04 \%$ & $3.52 \%$ & $9.78 \%$ & $19.17 \%$ & $20.10 \%$ & $88.73 \%$ & $24.22 \%$ \\
\hline & \multirow{2}{*}{562} & 176 & 115 & 102 & 124 & 183 & 155 & 225 & 379 & 502 & 195 & \\
\hline & & $3.41 \%$ & $0.00 \%$ & $0.00 \%$ & $0.81 \%$ & $8.74 \%$ & $2.58 \%$ & $10.22 \%$ & $16.62 \%$ & $11.75 \%$ & $47.69 \%$ & $16.27 \%$ \\
\hline & \multirow{2}{*}{525} & 453 & 375 & 481 & 396 & 541 & 572 & 445 & 710 & 623 & 933 & \\
\hline & & $1.99 \%$ & $2.13 \%$ & $0.42 \%$ & $0.51 \%$ & $2.59 \%$ & $1.22 \%$ & $2.47 \%$ & $7.04 \%$ & $11.88 \%$ & $37.19 \%$ & $10.40 \%$ \\
\hline & \multirow{2}{*}{526} & 309 & 200 & 272 & 326 & 173 & 173 & 162 & 193 & 103 & 151 & \\
\hline & & $2.27 \%$ & $5.00 \%$ & $0.37 \%$ & $3.07 \%$ & $1.73 \%$ & $4.62 \%$ & $4.94 \%$ & $23.32 \%$ & $12.62 \%$ & $39.73 \%$ & $14.49 \%$ \\
\hline & \multirow{2}{*}{551} & 5 & 4 & 6 & 2 & 1 & 3 & 2 & 1 & 1 & 0 & \\
\hline & & $0.00 \%$ & $0.00 \%$ & $0.00 \%$ & $0.00 \%$ & $0.00 \%$ & $0.00 \%$ & $0.00 \%$ & $0.00 \%$ & $0.00 \%$ & $0.00 \%$ & $0.00 \%$ \\
\hline & \multirow{2}{*}{552} & 2 & 4 & 0 & 4 & 4 & 12 & 5 & 6 & 4 & 4 & \\
\hline & & $0.00 \%$ & $0.00 \%$ & $0.00 \%$ & $0.00 \%$ & $0.00 \%$ & $0.00 \%$ & $0.00 \%$ & $0.00 \%$ & $0.00 \%$ & $50.00 \%$ & $0.00 \%$ \\
\hline & \multirow{2}{*}{541} & 9 & 14 & 29 & 21 & 10 & 6 & 9 & 7 & 10 & 13 & \\
\hline & & $0.00 \%$ & $0.00 \%$ & $0.00 \%$ & $0.00 \%$ & $0.00 \%$ & $0.00 \%$ & $0.00 \%$ & $0.00 \%$ & $0.00 \%$ & $7.69 \%$ & $1.28 \%$ \\
\hline & \multirow{2}{*}{542} & 3 & 4 & 4 & 1 & 5 & 5 & 0 & 3 & 1 & 1 & \\
\hline & & $0.00 \%$ & $0.00 \%$ & $0.00 \%$ & $0.00 \%$ & $0.00 \%$ & $0.00 \%$ & $0.00 \%$ & $0.00 \%$ & $0.00 \%$ & $0.00 \%$ & $0.00 \%$ \\
\hline & \multirow{2}{*}{543} & 4 & 1 & 6 & 3 & 4 & 5 & 8 & 6 & 8 & 6 & \\
\hline & & $0.00 \%$ & $0.00 \%$ & $0.00 \%$ & $0.00 \%$ & $0.00 \%$ & $0.00 \%$ & $0.00 \%$ & $0.00 \%$ & $0.00 \%$ & $16.67 \%$ & $2.78 \%$ \\
\hline
\end{tabular}


APPENDIX 1. (Continued). Total number of bottom trawl trips and percent sampled by sub-region, statistical area, and year (Gulf of Maine = GOM; Georges Bank = GB; Southern New England $=$ SNE; Northern mid-Atlantic $=$ NMA; Southern mid-Atlantic $=$ SMA). Trips that fished in more than one statistical area were treated as separate trips. The years 2000-2005 were selected for predicting small cetacean bycatch mortality.

\begin{tabular}{|c|c|c|c|c|c|c|c|c|c|c|c|c|}
\hline $\begin{array}{l}\text { Sub- } \\
\text { region }\end{array}$ & $\begin{array}{l}\text { Stat. } \\
\text { area }\end{array}$ & 1996 & 1997 & 1998 & 1999 & 2000 & 2001 & 2002 & 2003 & 2004 & 2005 & $\begin{array}{c}\text { Mean } \\
\text { sampling } \\
\text { coverage }\end{array}$ \\
\hline \multirow[t]{16}{*}{ SNE } & \multirow{2}{*}{537} & 3175 & 2862 & 2652 & 2693 & 2434 & 2435 & 2311 & 1865 & 1984 & 1925 & \multirow[b]{2}{*}{$2.33 \%$} \\
\hline & & $0.50 \%$ & $1.08 \%$ & $0.53 \%$ & $1.00 \%$ & $0.53 \%$ & $0.82 \%$ & $0.56 \%$ & $1.50 \%$ & $2.62 \%$ & $7.95 \%$ & \\
\hline & \multirow[t]{2}{*}{538} & $\begin{array}{r}2280 \\
075 \%\end{array}$ & 1998 & 1682 & 2239 & $\begin{array}{r}1758 \\
0.1 \%\end{array}$ & 1326 & 1652 & 1413 & 1742 & $\begin{array}{r}1296 \\
12550\end{array}$ & \multirow{2}{*}{$3.37 \%$} \\
\hline & & 年 & 1.1070 & 0.1270 & 0.780 & 0.017 & 0.0070 & 1.2170 & 1.7270 & 5.180 & 12.00 & \\
\hline & \multirow{2}{*}{539} & 2962 & 3312 & 4015 & 3930 & 3517 & 3116 & 3349 & 3105 & 2956 & 2688 & \multirow[b]{2}{*}{$2.04 \%$} \\
\hline & & $0.98 \%$ & $0.45 \%$ & $0.15 \%$ & $0.00 \%$ & $0.63 \%$ & $0.87 \%$ & $0.90 \%$ & $2.19 \%$ & $2.94 \%$ & $4.69 \%$ & \\
\hline & \multirow{2}{*}{611} & 3914 & 3586 & 4582 & 4696 & 4323 & 4111 & 4495 & 4790 & 4626 & 4207 & \multirow[b]{2}{*}{$0.60 \%$} \\
\hline & & $0.38 \%$ & $0.14 \%$ & $0.02 \%$ & $0.00 \%$ & $0.21 \%$ & $0.22 \%$ & $0.07 \%$ & $0.29 \%$ & $0.86 \%$ & $1.97 \%$ & \\
\hline & \multirow{2}{*}{612} & 3179 & 3323 & 3042 & 3110 & 3084 & 2891 & 3099 & 2521 & 2549 & 2807 & \multirow[b]{2}{*}{$1.40 \%$} \\
\hline & & $1.67 \%$ & $0.36 \%$ & $0.53 \%$ & $0.32 \%$ & $0.71 \%$ & $0.80 \%$ & $0.45 \%$ & $1.71 \%$ & $3.26 \%$ & $1.50 \%$ & \\
\hline & \multirow{2}{*}{613} & 2690 & 3623 & 2993 & 3602 & 5216 & 4131 & 4513 & 3163 & 3588 & 2837 & \multirow[b]{2}{*}{$0.99 \%$} \\
\hline & & $0.67 \%$ & $0.75 \%$ & $0.70 \%$ & $1.11 \%$ & $0.46 \%$ & $1.53 \%$ & $0.91 \%$ & $0.13 \%$ & $1.78 \%$ & $1.16 \%$ & \\
\hline & \multirow{2}{*}{533} & & & 13 & 9 & 5 & 8 & 3 & 11 & 4 & 11 & \multirow[b]{2}{*}{$0.00 \%$} \\
\hline & & $0.00 \%$ & $0.00 \%$ & $0.00 \%$ & $0.00 \%$ & $0.00 \%$ & $0.00 \%$ & $0.00 \%$ & $0.00 \%$ & $0.00 \%$ & $0.00 \%$ & \\
\hline & \multirow{2}{*}{534} & 19 & 15 & 11 & 14 & 20 & 31 & 13 & 10 & 14 & 19 & \multirow[b]{2}{*}{$0.00 \%$} \\
\hline & & $0.00 \%$ & $0.00 \%$ & $0.00 \%$ & $0.00 \%$ & $0.00 \%$ & $0.00 \%$ & $0.00 \%$ & $0.00 \%$ & $0.00 \%$ & $0.00 \%$ & \\
\hline $\begin{array}{l}\text { Sub- } \\
\text { region }\end{array}$ & $\begin{array}{l}\text { Stat. } \\
\text { area }\end{array}$ & 1996 & 1997 & 1998 & 1999 & 2000 & 2001 & 2002 & 2003 & 2004 & 2005 & $\begin{array}{c}\text { Mean } \\
\text { sampling } \\
\text { coverage } \\
\end{array}$ \\
\hline \multirow[t]{24}{*}{ NMA } & \multirow{2}{*}{614} & 189 & 194 & 187 & 127 & 95 & 83 & 47 & 123 & 171 & 265 & \\
\hline & & $3.17 \%$ & $0.00 \%$ & $0.00 \%$ & $3.15 \%$ & $2.11 \%$ & $2.41 \%$ & $2.13 \%$ & $4.88 \%$ & $11.11 \%$ & $2.26 \%$ & $4.15 \%$ \\
\hline & 615 & 219 & 257 & 84 & 114 & 157 & 192 & 105 & 138 & 211 & 121 & \\
\hline & 015 & $5.2 \%$ & $4.28 \%$ & $3.57 \%$ & $3.51 \%$ & $3.82 \%$ & $4.69 \%$ & $2.86 \%$ & $3.62 \%$ & $7.58 \%$ & $3.31 \%$ & $4.31 \%$ \\
\hline & 616 & 1516 & 1271 & 1348 & 965 & 929 & 990 & 997 & 939 & 1269 & 1318 & \\
\hline & 010 & $0.99 \%$ & $2.60 \%$ & $2.08 \%$ & $1.66 \%$ & $1.61 \%$ & $2.22 \%$ & $0.80 \%$ & $0.85 \%$ & $5.76 \%$ & $5.01 \%$ & $2.71 \%$ \\
\hline & 621 & 1221 & 1344 & 1424 & 1190 & 927 & 731 & 977 & 845 & 1261 & 1356 & \\
\hline & 021 & $4.10 \%$ & $0.15 \%$ & $0.14 \%$ & $1.09 \%$ & $2.27 \%$ & $9.17 \%$ & $7.27 \%$ & $4.02 \%$ & $2.78 \%$ & $1.11 \%$ & $4.44 \%$ \\
\hline & 622 & 635 & 392 & 699 & 488 & 295 & 415 & 380 & 529 & 1037 & 661 & \\
\hline & 022 & $6.14 \%$ & $6.38 \%$ & $2.29 \%$ & $2.46 \%$ & $11.53 \%$ & $4.82 \%$ & $2.89 \%$ & $4.73 \%$ & $7.71 \%$ & $5.60 \%$ & $6.21 \%$ \\
\hline & 623 & & 31 & 43 & 46 & 27 & 49 & 45 & 93 & 161 & 106 & \\
\hline & 023 & $1.82 \%$ & $19.35 \%$ & $18.60 \%$ & $0.00 \%$ & $11.11 \%$ & $6.12 \%$ & $2.22 \%$ & $9.68 \%$ & $10.56 \%$ & $8.49 \%$ & $6.36 \%$ \\
\hline & 624 & & & 1 & 0 & 2 & & 3 & 4 & 1 & 2 & \\
\hline & 024 & $0.00 \%$ & $0.00 \%$ & $0.00 \%$ & $0.00 \%$ & $0.00 \%$ & $0.00 \%$ & $0.00 \%$ & $0.00 \%$ & $0.00 \%$ & $0.00 \%$ & $0.00 \%$ \\
\hline & 625 & 184 & 170 & 105 & 120 & 72 & 86 & 335 & 163 & 139 & 136 & \\
\hline & $0 \angle 5$ & $2.17 \%$ & $1.18 \%$ & $0.00 \%$ & $1.67 \%$ & $5.56 \%$ & $2.33 \%$ & $1.49 \%$ & $4.91 \%$ & $2.88 \%$ & $3.68 \%$ & $3.47 \%$ \\
\hline & 626 & 279 & 165 & 375 & 406 & 371 & 304 & 248 & 488 & 784 & 1256 & \\
\hline & 020 & $6.09 \%$ & $4.85 \%$ & $1.87 \%$ & $0.99 \%$ & $9.97 \%$ & $1.64 \%$ & $0.81 \%$ & $5.53 \%$ & $3.32 \%$ & $1.03 \%$ & $3.72 \%$ \\
\hline & 627 & 10 & 7 & 19 & 11 & 7 & 11 & 8 & 8 & 14 & 23 & \\
\hline & 021 & $50 \%$ & $28.57 \%$ & $21.05 \%$ & $18.18 \%$ & $14.29 \%$ & 27.27 & $0.00 \%$ & $0.00 \%$ & $28.57 \%$ & $4.35 \%$ & $12.41 \%$ \\
\hline & 628 & 4 & 0 & 4 & 4 & 1 & 0 & 1 & 1 & 3 & 9 & \\
\hline & 028 & $0.00 \%$ & $0.00 \%$ & $0.00 \%$ & $0.00 \%$ & $0.00 \%$ & $0.00 \%$ & $0.00 \%$ & $0.00 \%$ & $0.00 \%$ & $0.00 \%$ & $0.00 \%$ \\
\hline & 629 & 0 & 0 & 1 & 0 & 0 & 1 & 0 & 0 & 0 & 1 & \\
\hline & 029 & $0.00 \%$ & $0.00 \%$ & $0.00 \%$ & $0.00 \%$ & $0.00 \%$ & $0.00 \%$ & $0.00 \%$ & $0.00 \%$ & $0.00 \%$ & $0.00 \%$ & $0.00 \%$ \\
\hline
\end{tabular}


APPENDIX 1. (Continued). Total number of bottom trawl trips and percent sampled by sub-region, statistical area, and year (Gulf of Maine $=$ GOM; Georges Bank = GB; Southern New England = SNE; Northern mid-Atlantic = NMA; Southern mid-Atlantic $=$ SMA). Trips that fished in more than one statistical area were treated as separate trips. The years 2000-2005 were selected for predicting small cetacean bycatch mortality.

\begin{tabular}{|c|c|c|c|c|c|c|c|c|c|c|c|c|}
\hline $\begin{array}{l}\text { Sub- } \\
\text { region }\end{array}$ & $\begin{array}{l}\text { Stat. } \\
\text { area }\end{array}$ & 1996 & 1997 & 1998 & 1999 & 2000 & 2001 & 2002 & 2003 & 2004 & 2005 & $\begin{array}{c}\text { Mean } \\
\text { sampling } \\
\text { coverage }\end{array}$ \\
\hline \multirow[t]{24}{*}{ SMA } & \multirow{2}{*}{631} & 57 & 198 & 289 & 160 & 234 & 277 & 326 & 200 & 98 & 55 & \\
\hline & & $8.77 \%$ & $3.03 \%$ & $1.38 \%$ & $0.63 \%$ & $6.41 \%$ & $0.00 \%$ & $3.37 \%$ & $5.50 \%$ & $3.06 \%$ & $1.82 \%$ & $3.36 \%$ \\
\hline & \multirow{2}{*}{632} & 191 & 93 & 221 & 127 & 124 & 100 & 46 & 108 & 105 & 66 & \\
\hline & & $5.24 \%$ & $5.38 \%$ & $0.00 \%$ & $2.36 \%$ & $5.65 \%$ & $0.00 \%$ & $0.00 \%$ & $14.81 \%$ & $11.43 \%$ & $19.70 \%$ & $8.60 \%$ \\
\hline & \multirow{2}{*}{633} & 5 & 3 & 4 & 14 & 5 & 3 & 0 & 9 & 4 & 2 & \\
\hline & & $0.00 \%$ & $0.00 \%$ & $0.00 \%$ & $0.00 \%$ & $0.00 \%$ & $0.00 \%$ & $0.00 \%$ & $0.00 \%$ & $0.00 \%$ & $0.00 \%$ & $0.00 \%$ \\
\hline & \multirow{2}{*}{634} & 1 & 0 & 0 & 1 & 0 & 1 & 0 & 0 & 0 & 0 & \\
\hline & & $0.00 \%$ & $0.00 \%$ & $0.00 \%$ & $0.00 \%$ & $0.00 \%$ & $0.00 \%$ & $0.00 \%$ & $0.00 \%$ & $0.00 \%$ & $0.00 \%$ & $0.00 \%$ \\
\hline & \multirow{2}{*}{635} & 256 & 485 & 489 & 402 & 328 & 430 & 357 & 346 & 1 & 173 & \\
\hline & & $0.78 \%$ & $0.62 \%$ & $1.64 \%$ & $3.23 \%$ & $2.44 \%$ & $0.00 \%$ & $1.68 \%$ & $0.87 \%$ & $100.00 \%$ & $5.20 \%$ & $18.36 \%$ \\
\hline & \multirow{2}{*}{636} & & 42 & 42 & 54 & 15 & 20 & 11 & 16 & 9 & 20 & \\
\hline & & $11.11 \%$ & $2.38 \%$ & $0.00 \%$ & $1.85 \%$ & $20.00 \%$ & $0.00 \%$ & $0.00 \%$ & $12.50 \%$ & $33.33 \%$ & $15.00 \%$ & $13.47 \%$ \\
\hline & \multirow{2}{*}{637} & 0 & 1 & 1 & 2 & 18 & 0 & 1 & 5 & 3 & 2 & \\
\hline & & $0.00 \%$ & $0.00 \%$ & $0.00 \%$ & $0.00 \%$ & $0.00 \%$ & $0.00 \%$ & $0.00 \%$ & $0.00 \%$ & $0.00 \%$ & $0.00 \%$ & $0.00 \%$ \\
\hline & \multirow{2}{*}{638} & 4 & 34 & 34 & 0 & 0 & 0 & 0 & 0 & 0 & 1 & \\
\hline & & $0.00 \%$ & $0.00 \%$ & $0.00 \%$ & $0.00 \%$ & $0.00 \%$ & $0.00 \%$ & $0.00 \%$ & $0.00 \%$ & $0.00 \%$ & $0.00 \%$ & $0.00 \%$ \\
\hline & \multirow{2}{*}{639} & 1 & 4 & 4 & 3 & 4 & 2 & 3 & 0 & 2 & 4 & \\
\hline & & $100 \%$ & $0.00 \%$ & $0.00 \%$ & $0.00 \%$ & $0.00 \%$ & $0.00 \%$ & $0.00 \%$ & $0.00 \%$ & $0.00 \%$ & $0.00 \%$ & $0.00 \%$ \\
\hline & \multirow{2}{*}{701} & 76 & 116 & 116 & 26 & 14 & 26 & 0 & 3 & 1 & 0 & \\
\hline & & $0.00 \%$ & $0.00 \%$ & $0.00 \%$ & $11.54 \%$ & $14.29 \%$ & $0.00 \%$ & $0.00 \%$ & $0.00 \%$ & $0.00 \%$ & $0.00 \%$ & $2.38 \%$ \\
\hline & \multirow{2}{*}{702} & 17 & 16 & 16 & 6 & 20 & 12 & 1 & 0 & 0 & 0 & \\
\hline & & $0.00 \%$ & $0.00 \%$ & $0.00 \%$ & $16.67 \%$ & $5.00 \%$ & $0.00 \%$ & $0.00 \%$ & $0.00 \%$ & $0.00 \%$ & $0.00 \%$ & $0.83 \%$ \\
\hline & \multirow{2}{*}{703} & 0 & 0 & 0 & 5 & 2 & 0 & 0 & 1 & 0 & 0 & \\
\hline & & $0.00 \%$ & $0.00 \%$ & $0.00 \%$ & $0.00 \%$ & $100.00 \%$ & $0.00 \%$ & $0.00 \%$ & $100.00 \%$ & $0.00 \%$ & $0.00 \%$ & $33.33 \%$ \\
\hline
\end{tabular}

